\title{
Bcl2110 induces metabolic alterations in ovarian cancer cells by regulating the TCA cycle enzymes SDHD and IDH1
}

\author{
SU-YEON LEE, JINIE KWON and KYUNG-AH LEE
}

Department of Biomedical Science, College of Life Science, CHA University, Seongnam, Gyeonggi 13488, Republic of Korea

Received September 29, 2020; Accepted February 3, 2021

DOI: $10.3892 /$ or.2021.7998

\begin{abstract}
Bcl2-like-10 (Bcl2110) has both oncogenic and tumor suppressor functions depending on the type of cancer. It has been previously demonstrated that the suppression of Bcl2110 in ovarian cancer SKOV3 and A2780 cells causes cell cycle arrest and enhances cell proliferation, indicating that $\mathrm{Bcl} 2110$ is a tumor suppressor gene in ovarian cancer cells. The aim of the present study was to identify possible downstream target genes and investigate the underlying mechanisms of action of $\mathrm{Bcl} 2110$ in ovarian cancer cells. RNA sequencing (RNA-Seq) was performed to obtain a list of differentially expressed genes (DEGs) in Bcl2110-suppressed SKOV3 and A2780 cells. The RNA-Seq data were validated by reverse transcription-quantitative PCR (RT-qPCR) and western blot analysis, and the levels of metabolites after Bcl2110-knockdown were measured using colorimetric assay kits. Pathway enrichment analysis revealed that the commonly downregulated genes in SKOV3 and A2780 cells after Bcl2110-knockdown were significantly enriched in metabolic pathways. The analysis of the DEGs identified from RNA-Seq and validated by RT-qPCR revealed that succinate dehydrogenase complex subunit D (SDHD) and isocitrate dehydrogenase 1 (IDH1), which are key enzymes of the TCA cycle that regulate oncometabolite production, may be potential downstream targets of Bcl2110. Furthermore, Bcl2110-knockdown induced the accumulation of succinate and isocitrate through the downregulation of SDHD and IDH1. The present study was the first to elucidate the metabolic regulatory functions of $\mathrm{Bcl} 2110$ in ovarian cancer cells,
\end{abstract}

Correspondence to: Professor Kyung-Ah Lee, Department of Biomedical Science, College of Life Science, CHA University, 335 Pangyo-ro, Bundang, Seongnam, Gyeonggi 13488, Republic of Korea

E-mail: leeka@cha.ac.kr

Abbreviations: DEG, differentially expressed gene; SDHD, succinate dehydrogenase complex subunit D; IDH1, isocitrate dehydrogenase 1; Bcl2110, Bcl2-like-10

Key words: Bcl2110, ovarian cancer, RNA sequencing, SDHD, IDH1 and the results indicated that $\mathrm{Bcl} 2110$ may serve as a potential therapeutic target in ovarian cancer.

\section{Introduction}

Over the past years, cutting-edge research and advanced screening, surgical and therapeutic technologies have contributed to increasing the 5-year relative survival rate for all types of cancer from 68 to $86 \%$ from 2010 to 2016 in adolescents in the United States (1). Despite these advances, the 5-year overall survival rate for advanced ovarian cancer remains $29 \%$ after diagnosis, as determined by statistics from 2008 to 2014 in the USA (2). Ovarian cancer is the seventh most common type of cancer worldwide and the second most common cause of cancer-associated death among women with gynecological malignancies (3). Although $\sim 70 \%$ of ovarian cancer cases are diagnosed at a late stage, patients usually respond well to primary therapy using cytoreductive surgery followed by adjuvant chemotherapy (4). Nevertheless, $75-85 \%$ of patients relapse, with a median progression-free survival time of 12-18 months, and exhibit resistance to chemotherapy, which leads to a decrease in the 5-year survival rate to $<50 \%$ (5). Thus, the discovery of new therapeutic targets and the elucidation of their mechanisms of action are required to improve the prognosis and treatment of ovarian cancer.

Bcl2-like-10 (Bcl2110), also called Diva, Bcl-b or Boo, is a member of the Bcl-2 family of proteins, which are central mediators of apoptosis and autophagy (6). Previous studies have revealed that $\mathrm{Bcl} 2110$ exhibits both pro-apoptotic and anti-apoptotic functions depending on the type of cells or tissues, and is recognized for its dual pro-apoptotic $(7,8)$ and anti-apoptotic activities $(9,10)$. $\mathrm{Bcl} 2110$ has been reported to have oncogenic functions in myelodysplastic syndromes, acute myeloid leukemia (AML), glioma and breast cancer $(9,11,12)$, but it acts as a tumor suppressor gene in gastric and lung cancer cells $(13,14)$. Based on our previous findings that $\mathrm{Bcl} 2110$ regulates cytoskeletal organization as a functional partner of Aurora kinase A (AURKA) during mouse oocyte maturation (15), it was hypothesized that $\mathrm{Bcl} 2110$ may have oncogenic functions in ovarian cancer, since AURKA has been reported as an oncogene $(16,17)$. However, our recent study has revealed that $\mathrm{Bcl} 2110$ is a tumor suppressor gene in human ovarian cancer cells (18). Specifically, the suppression of Bcl2110 in SKOV3 and A2780 cells causes cell cycle arrest at the $\mathrm{G}_{0} / \mathrm{G}_{1}$ phase and stimulates cell proliferation independently of 
apoptotic regulation (18). The current study aimed to clarify the molecular mechanism underlying the oncogenic effects induced by Bcl2110-knockdown in ovarian cancer cells.

\section{Materials and methods}

Cell culture. Two ovarian cancer cell lines were used in the present study. SKOV3 cells were obtained from the Korean Cell Line Bank (Korean Cell Line Research Foundation) and maintained in RPMI-1640 medium (Gibco; Thermo Fisher Scientific, Inc.) containing 10\% FBS (Gibco; Thermo Fisher Scientific, Inc.), $25 \mathrm{mM}$ HEPES (Gibco; Thermo Fisher Scientific, Inc.) and $25 \mathrm{mM} \mathrm{NaHCO}_{3}$ (Sigma-Aldrich; Merck $\mathrm{KGaA}$ ). A2780 cells were obtained from CellBank Australia and maintained in RPMI-1640 medium containing 10\% FBS. All cells were cultured in a $5 \% \mathrm{CO}_{2}$ atmosphere at $37^{\circ} \mathrm{C}$.

Cell transfection. Bcl2110 small interfering (si)RNA was synthesized by Shanghai GenePharma Co., Ltd., and a non-targeting negative control siRNA was purchased from Bioneer Corporation. One day before transfection, A2780 $\left(2 \times 10^{5} /\right.$ well $)$ and SKOV3 $\left(1.5 \times 10^{5} /\right.$ well $)$ cells were seeded in 6-well plates, and before transfection, the medium was removed and replaced with $1.5 \mathrm{ml}$ fresh growth medium. All siRNA molecules were diluted in $0.25 \mathrm{ml}$ OPTI-MEM (Gibco; Thermo Fisher Scientific, Inc.) to a final concentration of $100 \mathrm{nM}$, and Lipofectamine ${ }^{\circledR} 3000$ (Invitrogen; Thermo Fisher Scientific, Inc.) was diluted in $0.25 \mathrm{ml}$ OPTI-MEM. The solutions were incubated individually for $5 \mathrm{~min}$ at room temperature and then combined, and the mixture was incubated for an additional $20 \mathrm{~min}$ at room temperature and then added to each well containing cells, which were maintained in a $5 \% \mathrm{CO}_{2}$ atmosphere at $37^{\circ} \mathrm{C}$ for $48 \mathrm{~h}$. All cells were harvested $48 \mathrm{~h}$ after transfection for subsequent experiments. The following Bcl2110 siRNA sequences were used: Sense, 5'-CAACAGCCUUCAUUUAUCU-3' and antisense, 5'-AGA UAAAUGAAGGCUGUUG-3'.

Total RNA extraction and cDNA synthesis. After the cultured cells were washed twice with PBS, 1 ml TRIzol ${ }^{\circledR}$ (Takara Bio, Inc.) and $0.2 \mathrm{ml}$ chloroform were added, and the mixture was incubated for $10 \mathrm{~min}$ at room temperature. The cells were centrifuged at $12,000 \mathrm{xg}$ at $4^{\circ} \mathrm{C}$ for $20 \mathrm{~min}$, and the supernatants were transferred to new tubes and resuspended in $0.5 \mathrm{ml}$ isopropanol. The tubes were then centrifuged at $12,000 \mathrm{x} \mathrm{g}$ at $4^{\circ} \mathrm{C}$ for $10 \mathrm{~min}$, and the supernatants were discarded. The pellets were dried, washed with $75 \%$ ethanol, dried and dissolved in $0.1 \%$ diethylpyrocarbonate (DEPC)-treated water. For the synthesis of first-strand cDNA, total RNA $(2 \mu \mathrm{g})$ was added to DNase I and DNase I buffer (both New England BioLabs, Inc.), and the total volume was adjusted to $11 \mathrm{ml}$ with DEPC-treated water. After the mixture was incubated at room temperature for $15 \mathrm{~min}, 1 \mathrm{ml}$ of $25 \mathrm{mM}$ EDTA was added, and the mixture was incubated at $65^{\circ} \mathrm{C}$ for $15 \mathrm{~min}$. Subsequently, $1 \mathrm{ml}$ of oligo dT was added, and the mixture was incubated at $70^{\circ} \mathrm{C}$ for $10 \mathrm{~min}$. M-MLV RNase (Promega Corporation), 5X buffer (Promega Corporation), RNase inhibitor (Promega Corporation) and $10 \mathrm{mM}$ dNTP were then added, and reverse transcription was performed at $42^{\circ} \mathrm{C}$ for $1 \mathrm{~h}$ and $94^{\circ} \mathrm{C}$ for $2 \mathrm{~min}$.
Quantitative (q)PCR. qPCR analysis was performed using an iCycler system (Bio-Rad Laboratories, Inc.). iQ SYBR Green Supermix PCR reagents (Bio-Rad Laboratories, Inc.) were used for monitoring the amplification, and the results were evaluated with the iCycler iQ real-time detection system software. The amplification mixture contained cDNA, 5 pmol forward and reverse primers, and SYBR Green Supermix. qPCR involved an initial denaturation step at $95^{\circ} \mathrm{C}$ for $5 \mathrm{~min}$, followed by 40 cycles of denaturation at $95^{\circ} \mathrm{C}$ for $40 \mathrm{sec}$, annealing at $60^{\circ} \mathrm{C}$ for $40 \mathrm{sec}$ and extension at $72^{\circ} \mathrm{C}$ for $40 \mathrm{sec}$. Upon the completion of PCR, the fluorescence was monitored while slowly heating the samples from 55 to $95^{\circ} \mathrm{C}$ at $0.5^{\circ} \mathrm{C}$ intervals. Human GAPDH was used as the endogenous reference for mRNA normalization, and fold-changes were calculated using the $2^{-\Delta \Delta C q}$ method (19). The primer sequences used for qPCR are listed in Table I.

Western blot analysis. Proteins were extracted from the siRNA-transfected cells using RIPA lysis buffer with $1 \%$ protease inhibitor cocktail (Thermo Fisher Scientific, Inc.) and 0.5 M EDTA (pH 8.0). Protein concentration was estimated using the Bio-Rad protein assay reagent (Bio-Rad Laboratories, Inc.) according to the manufacturer's instructions. The protein extracts $(50 \mu \mathrm{g} / \mathrm{lane})$ were separated by $10 \%$ SDS-PAGE and transferred to PVDF membranes (Amersham; Cytiva). The membranes were blocked for $1 \mathrm{~h}$ at room temperature in TBS/Tween (TBST; $0.2 \mathrm{M} \mathrm{NaCl}, 0.1 \%$ Tween-20 and $10 \mathrm{mM}$ Tris, $\mathrm{pH}$ 7.4) containing 5\% skimmed dry milk. The immunoblots were incubated overnight at $4^{\circ} \mathrm{C}$ on a shaker with diluted polyclonal primary antibodies against BCL2L10 (cat. no. 3869S; Cell Signaling Technology, Inc.), succinate dehydrogenase complex subunit D (SDHD; cat. no. PA5-34387; Thermo Fisher Scientific, Inc.), isocitrate dehydrogenase 1 (IDH1; cat. no. 3997S; Cell Signaling Technology, Inc.), fumarate hydratase (FH; cat. no. GTX110128; GeneTex International Corporation), tropomyosin 4 (TPM4; cat. no. PA5-340194; Thermo Fisher Scientific, Inc.) and $\beta$-actin (cat. no. PA1-183; Invitrogen; Thermo Fisher Scientific, Inc.), all of which were diluted 1:1,000. The membranes were then washed several times with TBST and incubated with diluted HRP-conjugated goat anti-rabbit IgG secondary antibody (1:2,000; cat. no. 65-6120; Thermo Fisher Scientific, Inc.) for $1 \mathrm{~h}$ at room temperature. Finally, the membranes were washed several times with TBST, and Amersham ${ }^{\mathrm{TM}} \mathrm{ECL}^{\mathrm{TM}}$ Prime Western Blotting Detection Reagent (cat. no. RPN2232; GE Healthcare Life Sciences) was used to visualize chemiluminescence. The relative protein expression levels were quantified using the ChemiDoc XRS+ imaging system with Image Lab software version 6.0.0 (Bio-Rad Laboratories, Inc.).

$R N A$ isolation for sequencing. For RNA-Seq analysis, duplicate samples obtained from two repeated experiments were used.Total RNA was isolated from cells using TRIzol reagent (Invitrogen; Thermo Fisher Scientific, Inc.). The RNA quality was assessed using an Agilent 2100 bioanalyzer (Agilent Technologies, Inc.), and RNA quantification was performed using a NanoDrop 2000 Spectrophotometer (Thermo Fisher Scientific, Inc.).

Library preparation and sequencing. All RNA-Seq and analysis of sequencing data were performed by ebiogen, Inc. 
Table I. Primer sequences used for quantitative PCR.

\begin{tabular}{|c|c|c|}
\hline Genes & Forward sequences $\left(5^{\prime} \rightarrow 3^{\prime}\right)$ & Reverse sequences $\left(5^{\prime} \rightarrow 3^{\prime}\right)$ \\
\hline $\operatorname{Bcl} 2110$ & GGTCCTTTTTCTCCGCCTAC & CTGGAAGCCCCACTTCTTC \\
\hline ZNF845 & AGGCCTTCAGTCAGAAGTCATC & GTGTGAATCACGCCCAAAA \\
\hline MED11 & AGAGACTACGCGCTCTGGAA & AGGAGCCGCTCGTTAGTTTT \\
\hline POLR2D & TTGCCAGTGTTCGTAGCTTG & TGCAGCTCCTCATCTTCAAA \\
\hline FOXP4 & CACCAGGATGTTCGCCTATT & TTCTGATACTCCCGCTCGTC \\
\hline ZNF415 & AATTCACACCTTGCGAGTCA & GAAGCCTTTGCCACATTGAT \\
\hline НАBP4 & CGGAAACCAGAATCCACTGT & GCTGGGATGTGATGTCATTG \\
\hline SETD7 & GGGAACTTTGTTCACGGAGA & TCCCCCATCTTCGTAAGTGT \\
\hline ZNF721 & CCTTTGGATGGTCCACAAAC & AGCAAAGCTTGAGGATGACG \\
\hline VOPP1 & GATGAACCCTGTCGGGAAT & GGCCTTCACTACCTGTTCGTA \\
\hline ZNF765 & CATCTGCCTGAACTGCACAT & TTCTTTGGGCTGTTGAAACC \\
\hline ZSCAN29 & AGGAAGACAGTGGGCAAAGA & TCCCAAGCAAGGTCTCTGTT \\
\hline ZNF267 & CACACCTTATTCGACATCATCG & TGCACAGTAAGACCTGAGGAGT \\
\hline ACER2 & GCAGTCCTTTGGGTTCTGAT & TGTTGATGGCAGGCTTGA \\
\hline SDHD & CTGGAGGCTGAGTGCCGTTT & TCTGGGATAGGTCGGTCCTGAA \\
\hline IDH1 & TTGTCCAGATGGCAAGACAG & CTCTGGTCCAGGCAAAAATG \\
\hline LCLAT1 & CATCCAAGGAGGACCTTCAA & CAGACTTGCAAGGTGGAATG \\
\hline ENOPH1 & CGAAAGACCACTGCACTCAA & CTCCGTAGAATGCCCGAATA \\
\hline IDI1 & CCGAGCTTGAGGAAAGTGAC & CATGTTCACCCCAGATACCA \\
\hline HPRT1 & GACCAGTCAACAGGGGACAT & CTTGCGACCTTGACCATCTT \\
\hline PAICS & CAGTGGTCTTGGCTGTTCAA & CAGCCTGCTTCAAGGAAATC \\
\hline ATP6V1D & GTGGGGAACAGTTGGCTAAA & GCATTTACACGCCTGTTGGT \\
\hline ACSL5 & TCCCGAATGGAACTCTGAAG & AGCTCTCCCCGTGTACAAAA \\
\hline TPM4 & CTGAGACCCGTGCTGAATTT & AGCCCACGTTCTCTTCTTTG \\
\hline GAPDH & TCAAGAAGGTGGTGAAGCAG & CCCTGTTGCTGTAGCCAAAT \\
\hline
\end{tabular}

Bcl2110, Bcl-2-like-10; SDHD, succinate dehydrogenase complex subunit D; IDH1, isocitrate dehydrogenase 1; TPM4, tropomyosin 4.

Libraries were prepared from total RNA using the SMARTer Stranded RNA Seq kit (cat. no. 634839; Clontech Laboratories, Inc.). mRNA isolation was performed using the Poly(A) RNA Selection kit (Lexogen $\mathrm{GmbH}$ ). The isolated mRNAs were used for cDNA synthesis and shearing according to the manufacturer's instructions (Clontech Laboratories, Inc.). Indexing was performed using Illumina indexes 1-12 found in Illumina Adapter Sequences (document no. 1000000002694, v14), and enrichment was conducted by PCR. Subsequently, the libraries were checked using the Agilent 2100 bioanalyzer (DNA High Sensitivity kit; Agilent Technologies, Inc.) to evaluate the mean fragment size. Quantification was performed using a library quantification kit and a StepOne Real Time PCR System (Thermo Fisher Scientific, Inc.). High-throughput sequencing was performed as paired-end $100 \mathrm{bp}$ sequencing using the HiSeq 2500 system (Illumina, Inc.).

Analysis of RNA sequencing (RNA-Seq) data. Quality control of the raw sequencing data was performed using FastQC (https://www.bioinformatics.babraham.ac.uk/projects/fastqc/). Adapter and low-quality reads $(<\mathrm{Q} 20)$ were removed using FASTX_Trimmer (http://hannonlab.cshl. edu/fastx_toolkit/) and BBMap (https://sourceforge.net/projects/bbmap/). The trimmed reads were mapped to the UCSC
Human genome (hg19) using TopHat (20). Gene expression levels were estimated based on read count and Fragments Per Kilobase Million values calculated using BEDTools (21) and Cufflinks (22). The expression values were normalized based on the quantile normalization method using edgeR within $\mathrm{R}$ (https://www.r-project.org/). Data mining and graphic visualization were performed using ExDEGA V3.0.1 (ebiogen, Inc.). To define differentially expressed genes (DEGs), adjusted $\mid \log _{2}$ fold-change $(\mathrm{FC}) \mid \geq 1$ and $\mathrm{P}<0.05$ were selected as the cut-off values. The functions and associated pathways of the DEGs were further analyzed using the Gene Ontology (GO) and Kyoto Encyclopedia of Genes and Genomes (KEGG) pathway using the DAVID database (https://david.ncifcrf. gov/).

Measurement of levels of succinate and isocitrate. Cellular contents of succinate and isocitrate in ovarian cancer cells after Bcl2110-knockdown were measured using a succinate colorimetric assay kit (cat. no. K649-100; BioVision, Inc.) and isocitrate colorimetric assay kit (cat. no. K656-100; BioVision, Inc.), according to the manufacturer's instructions. Briefly, cells $\left(2 \times 10^{6}\right)$ were rapidly homogenized on ice using $100 \mu \mathrm{l}$ of ice-cold supplied-assay buffer and centrifuged at $4{ }^{\circ} \mathrm{C}$ at $10,000 \times \mathrm{g}$ for $5 \mathrm{~min}$ (succinate) or $15,000 \mathrm{x} \mathrm{g}$ for $10 \mathrm{~min}$ 
(isocitrate) to remove any cell debris. Supernatants $(50 \mu \mathrm{l})$ were collected and diluted 1:1 with assay buffer. The samples were then added to duplicate wells in a 96-well plate and mixed with the appropriate reaction mix. The resultant mixtures were further incubated at $37^{\circ} \mathrm{C}$ for $30 \mathrm{~min}$. The concentrations were determined using a microplate reader at a wavelength of $450 \mathrm{~nm}$ and calculated based on a standard curve.

Statistical analysis. The statistical analysis was performed using GraphPad Prism 9.0 (GraphPad Software, Inc.). The data are presented as the mean \pm SEM from four independent experiments. The differences between the negative control and the Bcl2110 siRNA-treated groups were analyzed using unpaired Student's t-test. $\mathrm{P}<0.05$ was considered to indicate a statistically significant difference.

\section{Results}

Identification of DEGs by Bcl2l10 suppression. To investigate the molecular mechanisms through which Bcl2110 may exert anticancer effects on ovarian cancer cells, a list of DEGs after Bcl2110-knockdown in two ovarian cancer cell lines, SKOV3 and A2780, was obtained by RNA-Seq. The volcano plots from RNA-Seq data show the 25,737 expressed genes in both SKOV3 and A2780 cells after Bcl2110-knockdown (Fig. 1A and B). The number of significantly expressed genes in response to Bcl2110-knockdown with $\mathrm{P}<0.05$ was 3,852 and 3,296 in SKOV3 and A2780 cells, respectively. Using more stringent criteria ( $\log _{2} \mathrm{FCl} \geq 1$ and $\left.\mathrm{P}<0.05\right), 883$ and 545 significantly deregulated genes were selected in SKOV3 and A2780 cells, respectively. Of the 883 genes in SKOV3 cells, 263 genes were upregulated and 620 genes were downregulated (Fig. 1A). Of the 545 genes in A2780 cells, 248 genes were upregulated and 297 genes were downregulated (Fig. 1B). The Venn diagrams indicate that 31 genes were significantly upregulated, whereas 92 genes were significantly downregulated in both SKOV3 and A2780 cells (Fig. 1C and D). These 123 genes were classified as common DEGs regulated by $\mathrm{Bcl} 2110$ and used for further analysis. All common DEGs are listed in Tables II and III, and the relative expression levels of these genes are shown in a hierarchical clustering heat map (Fig. 1E). The present study subsequently focused on the common DEGs to further explore the roles of genes associated with $\mathrm{Bcl} 2110$ in ovarian cancer cells.

Characterization of common DEGs after Bcl2l10-knockdown. $\mathrm{GO}$ analysis of the 31 genes that were upregulated by Bcl2110-knockdown in both SKOV3 and A2780 cells indicated that these genes were enriched in five GO terms encompassing two biological process, one cellular compound (CC) and two molecular function terms (Table IV). As a result, it was identified that 13/31 commonly upregulated genes were involved in the regulation of transcription. In particular, the ranking of the 31 genes by FC indicated that the top 20 upregulated genes in both SKOV3 and A2780 cells included five genes (ZNF845, MED11, FOXP4, ZNF765 and ZNF702P) among the 13 genes associated with transcriptional regulation (Table SI). The most enriched CC term of the commonly upregulated genes after Bcl2110-knockdown was GO:0005634 'nucleus' (Table IV). The KEGG pathway analysis did not identify any pathway enriched in the list of genes that were upregulated by Bcl2110-knockdown in both cell lines.

Moreover, 92 genes were downregulated by Bcl2110-knockdown in both SKOV3 and A2780 cells. In contrast to the commonly upregulated genes, these downregulated genes were enriched in the terms 'cytoplasm' (GO:0005737), containing the cell regions excluding the plasma membrane and nucleus but including other subcellular structures, and 'protein binding' (GO:0005515) (Table V). GO analysis demonstrated that upregulated and downregulated genes after Bcl2110-knockdown may have clearly distinct functions in ovarian cancer progression. Although $\mathrm{P}>0.05$, the KEGG pathway analysis revealed that the commonly downregulated genes were mainly involved in 'metabolic pathways', 'biosynthesis of antibiotics' and 'pathways in cancer' (Table V). Notably, the largest proportion $(\sim 11 \%)$ of the commonly downregulated genes after Bcl2110-knockdown was involved in metabolic pathways. The ordering of the 92 commonly downregulated genes based on their FC in each cell line (in descending order) revealed that three metabolic genes (SDHD, ENOPH1 and ACER2) were included in the list of top 20 downregulated genes (Table SII), which suggested that Bcl 2110 strongly affected ovarian cancer metabolism. To validate the RNA-Seq findings that potential target genes of $\mathrm{Bcl} 2110$ regulated transcription and metabolism in cancer, the expression levels of some transcription- and metabolism-associated genes among the common DEGs after Bcl2110-knockdown were analyzed in two ovarian cancer cell lines.

Validation of DEGs as potential targets of Bcl2l10. To validate the reliability of the RNA-Seq data, 22/123 common DEGs in two ovarian cancer cell lines were selected, and their expression levels after $\mathrm{Bcl} 2110$-knockdown were examined by RT-qPCR using different sets of RNA samples from those used for RNA-Seq. Bcl2110-knockdown was confirmed to be successful using RT-qPCR (Fig. 2A and B). These 22 common DEGs included 12 upregulated genes associated with the regulation of transcription (ZNF845, MED11, POLR2D, FOXP4, ZNF415, HABP4, SETD7, ZNF721, VOPP1, ZNF765, ZSCAN29 and ZNF267) and 10 downregulated genes involved in metabolic pathways (ACER2, SDHD, IDH1, LCLAT1, ENOPH1, IDI1, HPRT1, PAICS, ATP6V1D and ACSL5) in SKOV3 and A2780 cells. The RT-qPCR data revealed that the expression levels of all 12 commonly upregulated genes were significantly higher in the Bcl2110-suppressed cells than in the control cells, and this finding was obtained for both ovarian cancer cell lines (Fig. 2A). In particular, the expression levels of SETD7 and VOPP1 were markedly elevated by Bcl2110-knockdown in both SKOV3 and A2780 cells (Fig. 2A).

Subsequently, whether Bcl2110-knockdown decreased the expression levels of metabolism-associated genes was analyzed by RT-qPCR. Among the 10 commonly downregulated genes that were tested by RT-qPCR, the expression levels of 8 genes (SDHD, IDH1, LCLAT1, ENOPH1, IDI1, HPRT1, PAICS and ATP6V1D) were significantly decreased in the Bcl2110-suppressed SKOV3 cells, whereas the expression levels of 9 genes (ACER2, SDHD, IDH1, LCLAT1, ENOPH1, IDI1, HPRT1, ATP6V1D and ACSL5) were significantly decreased in the Bcl2110-suppressed A2780 cells compared with their respective control cells (Fig. 2B). In particular, 
A

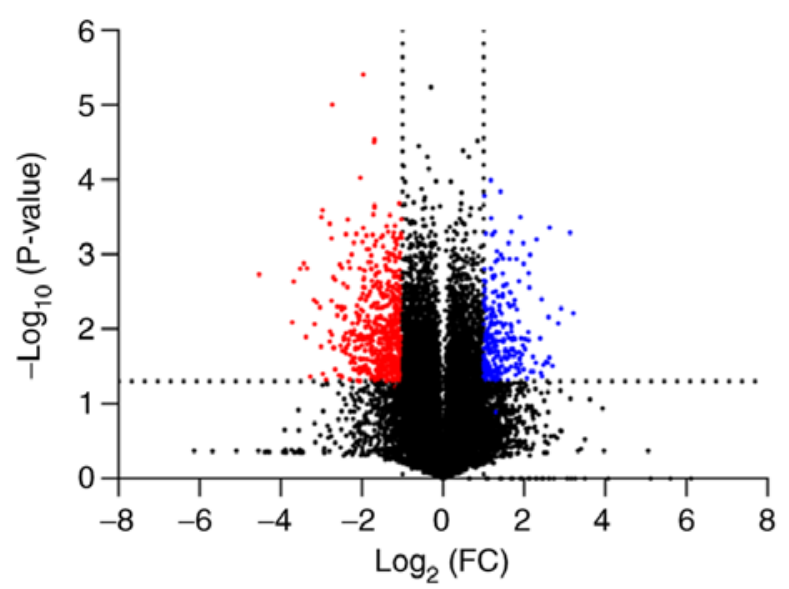

C Upregulated DEGs

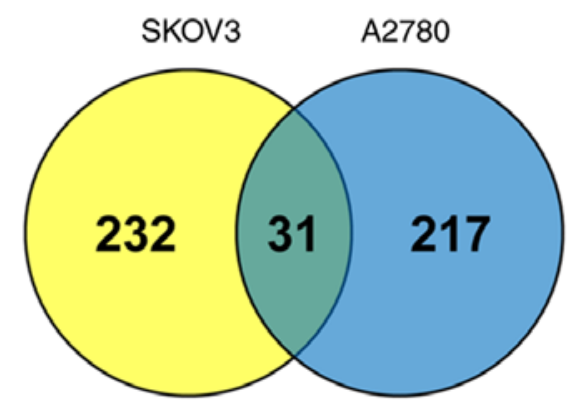

D Downregulated DEGs

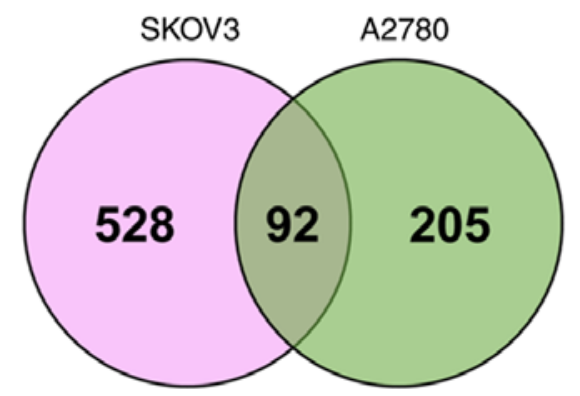

B

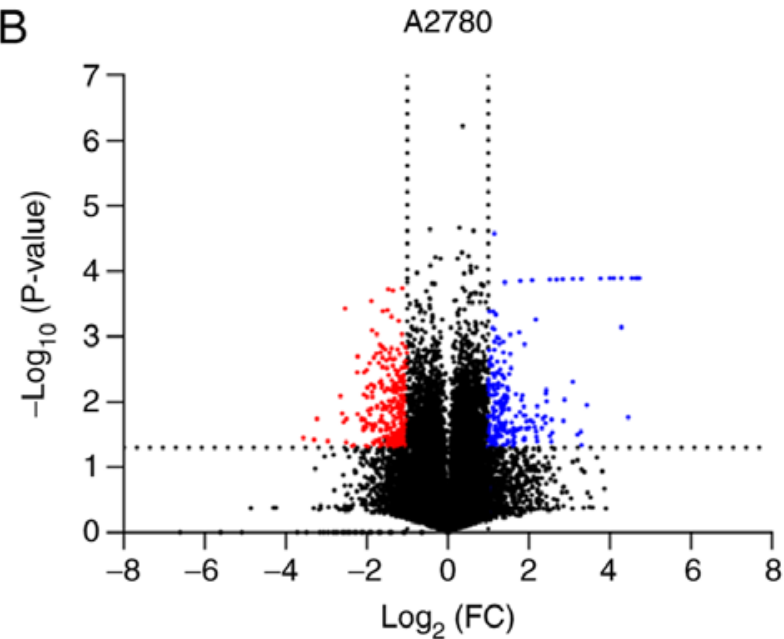

$\mathrm{E}$

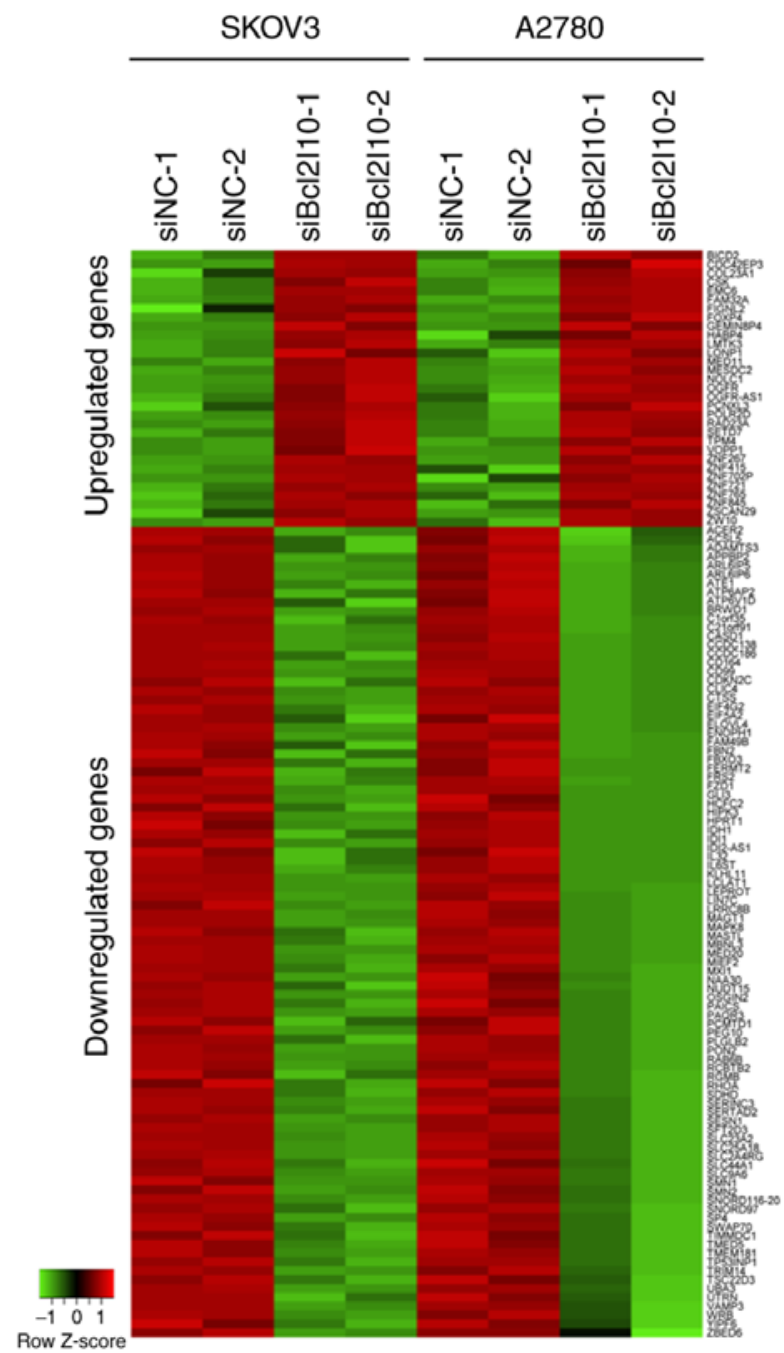

Figure 1. Identification of DEGs in ovarian cancer cell lines after Bcl2110-knockdown. Volcano plots of all the 25,737 expressed genes from RNA sequencing analysis upon Bcl2110-knockdown in (A) SKOV3 and (B) A2780 cells. The two vertical dashed lines correspond to $\log _{2}$ (FC) $\geq 1$ (right) and $\leq-1$ (left), and the horizontal dashed line represents $\mathrm{P}=0.05$ as the threshold cut-off. Blue dots represent significantly upregulated genes and red dots represent significantly downregulated genes. Venn diagrams showing DEGs that were (C) upregulated or (D) downregulated in both SKOV3 and A2780 cells after Bcl2110-knockdown. (E) Heat map showing the 123 common DEGs $\left[\log _{2}(\mathrm{FC}) \geq 1\right.$ and $\left.\mathrm{P}<0.05\right]$, which include 31 upregulated and 92 downregulated genes after Bcl2110-knockdown in SKOV3 and A2780 cells. The expression levels are plotted in the heat map with a color scale based on the Z-score. The red color represents upregulated genes, and the green color represents downregulated genes after Bcl2110-knockdown. Duplicate samples obtained from two repeated experiments were used (siNC-1/2 and siBCL2110-1/2). FC, fold-change; DEGs, differentially expressed genes; Bcl2110, Bcl-2-like-10; si, small interfering RNA; NC, negative control.

SDHD and IDH1 exhibited the greatest decrease in expression after Bcl2110-knockdown in both SKOV3 and A2780 cells.
To determine the association between Bc12110 and two metabolism-associated enzymes, SDHD and IDH1, the protein 
Table II. List of the commonly upregulated differentially expressed genes after Bcl2110-knockdown.

\begin{tabular}{|c|c|c|c|c|}
\hline \multirow[b]{2}{*}{ Gene } & \multicolumn{2}{|c|}{ SKOV 3 cells } & \multicolumn{2}{|c|}{ A2780 cells } \\
\hline & $\log _{2} \mathrm{FC}$ & $\mathrm{P}$-value & $\log _{2} \mathrm{FC}$ & P-value \\
\hline BICD2 & 1.65 & 0.003 & 1.44 & 0.010 \\
\hline CDC42EP3 & 1.06 & 0.001 & 1.01 & 0.049 \\
\hline COL23A1 & 1.52 & 0.023 & 1.51 & 0.013 \\
\hline CSK & 1.27 & 0.029 & 1.21 & 0.004 \\
\hline EMC6 & 1.87 & 0.002 & 1.56 & 0.003 \\
\hline FAM32A & 1.22 & 0.005 & 1.03 & 0.003 \\
\hline FIGNL2 & 1.99 & 0.034 & 1.54 & 0.001 \\
\hline FOXP4 & 1.49 & 0.015 & 1.35 & 0.027 \\
\hline GEMIN8P4 & 1.61 & 0.020 & 1.73 & 0.027 \\
\hline HABP4 & 1.65 & 0.005 & 1.09 & 0.045 \\
\hline LMTK3 & 1.53 & 0.037 & 1.65 & 0.034 \\
\hline LONP1 & 1.11 & 0.013 & 1.02 & 0.002 \\
\hline MED11 & 2.11 & 0.011 & 1.38 & 0.002 \\
\hline MESDC2 & 1.44 & 0.006 & 1.17 & 0.010 \\
\hline NOLC1 & 1.39 & 0.005 & 1.22 & 0.001 \\
\hline OGFR & 1.66 & 0.023 & 1.81 & 0.009 \\
\hline OGFR-AS1 & 1.44 & 0.025 & 1.39 & 0.013 \\
\hline PCNXL3 & 1.07 & 0.026 & 1.16 & 0.018 \\
\hline POLR2D & 1.20 & 0.005 & 1.15 & 0.004 \\
\hline RAD23A & 1.10 & 0.013 & 1.25 & 0.005 \\
\hline SETD7 & 1.12 & 0.020 & 1.13 & 0.008 \\
\hline TPM4 & 2.48 & 0.030 & 1.87 & 0.016 \\
\hline VOPP1 & 1.44 & 0.040 & 1.12 & 0.006 \\
\hline ZNF267 & 1.24 & 0.003 & 1.79 & 0.014 \\
\hline ZNF415 & 1.29 & 0.001 & 1.04 & 0.022 \\
\hline ZNF702P & 2.30 & 0.001 & 1.65 & 0.025 \\
\hline ZNF721 & 1.29 & 0.008 & 1.11 & 0.001 \\
\hline ZNF765 & 1.69 & 0.013 & 1.20 & 0.011 \\
\hline ZNF845 & 1.67 & 0.003 & 1.25 & 0.020 \\
\hline ZSCAN29 & 1.24 & 0.026 & 1.35 & 0.004 \\
\hline ZW10 & 1.18 & 0.005 & 1.11 & 0.012 \\
\hline
\end{tabular}

FC, fold-change; Bcl2110, Bcl-2-like-10; TPM4, tropomyosin 4.

expression levels of SDHD and IDH1 were further examined after Bcl2110-knockdown. As determined by western blot analysis, the protein expression levels of SDHD and IDH1 were significantly decreased after Bcl2110-knockdown in both SKOV3 and A2780 cells (Fig. 3A and B). Additionally, the alteration in FH expression was examined after Bcl2110-knockdown, since SDH, IDH1/2 and FH are all directly responsible for the initiation of cancer in the presence of remodeled TCA cycle (23), confirming that $\mathrm{FH}$ expression was not affected by Bcl2110-knockdown (Fig. 3A and B). These results suggested that Bcl2110 may be a substantial regulator of the TCA cycle.

Bcl2l10-knockdown induces the accumulation of succinate and isocitrate in ovarian cancer cells. Based on the downregulation of SDHD and IDH1 expression after
Table III. List of the commonly downregulated differentially expressed genes after Bcl2110-knockdown.

\begin{tabular}{|c|c|c|c|c|}
\hline \multirow[b]{2}{*}{ Gene } & \multicolumn{2}{|c|}{ SKOV3 cells } & \multicolumn{2}{|c|}{ A2780 cells } \\
\hline & $\log _{2} \mathrm{FC}$ & P-value & $\log _{2} \mathrm{FC}$ & P-value \\
\hline ACER2 & -2.61 & 0.005 & -1.63 & 0.006 \\
\hline ACSL5 & -1.53 & 0.021 & -2.02 & 0.047 \\
\hline ADAMTS3 & -1.56 & 0.019 & -1.09 & 0.010 \\
\hline APPBP2 & -1.35 & 0.008 & -1.39 & 0.002 \\
\hline ARL6IP5 & -1.84 & 0.001 & -1.90 & 0.005 \\
\hline ARL6IP6 & -1.49 & 0.001 & -1.36 & 0.010 \\
\hline ATE1 & -1.77 & 0.001 & -1.62 & 0.003 \\
\hline ATP6AP2 & -1.09 & 0.006 & -1.12 & 0.001 \\
\hline ATP6V1D & -2.73 & $<0.001$ & -1.13 & 0.001 \\
\hline BRWD1 & -1.16 & 0.033 & -1.54 & 0.002 \\
\hline C1orf35 & -1.30 & 0.002 & -1.15 & 0.018 \\
\hline C21orf91 & -1.83 & 0.003 & -1.34 & 0.007 \\
\hline CASD1 & -1.09 & 0.014 & -1.06 & 0.015 \\
\hline CCDC138 & -1.11 & 0.011 & -1.32 & 0.046 \\
\hline CCDC186 & -1.41 & 0.001 & -1.61 & 0.001 \\
\hline CD164 & -2.25 & 0.001 & -1.89 & $<0.001$ \\
\hline CD99 & -1.69 & $<0.001$ & -1.07 & 0.002 \\
\hline CDKN2C & -1.30 & 0.013 & -1.35 & 0.006 \\
\hline CLIC4 & -2.02 & 0.005 & -2.23 & 0.002 \\
\hline CTSS & -1.69 & 0.001 & -1.22 & 0.037 \\
\hline EIF4G2 & -2.75 & 0.001 & -1.67 & 0.001 \\
\hline EIF5A2 & -1.97 & 0.003 & -1.05 & 0.008 \\
\hline ELOVL4 & -3.17 & 0.009 & -2.54 & $<0.001$ \\
\hline ENOPH1 & -2.70 & 0.002 & -1.82 & 0.002 \\
\hline FAM49B & -1.91 & 0.004 & -1.38 & 0.005 \\
\hline FBN2 & -1.02 & 0.023 & -1.28 & 0.037 \\
\hline FBXO3 & -1.39 & $<0.001$ & -1.14 & 0.014 \\
\hline FERMT2 & -2.75 & 0.004 & -1.62 & 0.005 \\
\hline FRS2 & -1.08 & 0.015 & -1.05 & 0.015 \\
\hline FZD1 & -1.97 & 0.003 & -1.99 & 0.008 \\
\hline GLI3 & -1.09 & 0.025 & -1.02 & 0.003 \\
\hline HCFC2 & -1.29 & 0.008 & -1.13 & 0.033 \\
\hline HIPK3 & -1.94 & 0.003 & -1.50 & 0.003 \\
\hline HPRT1 & -1.31 & $<0.001$ & -1.51 & 0.003 \\
\hline IDH1 & -2.51 & 0.005 & -1.61 & 0.013 \\
\hline IDI1 & -1.03 & 0.012 & -1.18 & 0.017 \\
\hline IDI2-AS1 & -1.31 & 0.009 & -1.20 & 0.038 \\
\hline IL32 & -1.76 & 0.019 & -3.30 & 0.038 \\
\hline IL6ST & -2.43 & 0.013 & -1.57 & 0.011 \\
\hline KLHL11 & -1.20 & 0.004 & -1.17 & 0.004 \\
\hline LCLAT1 & -1.89 & 0.001 & -1.76 & 0.001 \\
\hline LEPROT & -1.16 & 0.006 & -1.35 & 0.002 \\
\hline LIN7C & -2.04 & $<0.001$ & -2.24 & 0.004 \\
\hline LRRC8B & -1.91 & 0.009 & -1.36 & 0.007 \\
\hline MAGT1 & -1.83 & 0.001 & -1.30 & 0.005 \\
\hline MAPK8 & -1.48 & 0.005 & -1.25 & 0.031 \\
\hline MASTL & -1.01 & 0.001 & -1.09 & 0.022 \\
\hline MBNL3 & -1.61 & 0.039 & -1.18 & 0.034 \\
\hline MED20 & -1.53 & 0.003 & -1.05 & 0.003 \\
\hline MIEF2 & -1.28 & 0.022 & -1.93 & 0.016 \\
\hline
\end{tabular}


Table III. Continued.

\begin{tabular}{|c|c|c|c|c|}
\hline \multirow[b]{2}{*}{ Gene } & \multicolumn{2}{|c|}{ SKOV3 cells } & \multicolumn{2}{|c|}{ A2780 cells } \\
\hline & $\log _{2} \mathrm{FC}$ & $\mathrm{P}$-value & $\log _{2} \mathrm{FC}$ & P-value \\
\hline MXI1 & -2.40 & 0.001 & -1.39 & $<0.001$ \\
\hline NAA30 & -1.62 & 0.002 & -1.10 & 0.006 \\
\hline NUDT15 & -2.05 & 0.004 & -1.11 & 0.005 \\
\hline OSGIN2 & -1.82 & 0.012 & -1.12 & 0.025 \\
\hline PAICS & -1.01 & 0.005 & -1.10 & 0.028 \\
\hline PAQR3 & -2.55 & 0.001 & -1.66 & 0.027 \\
\hline PCMTD1 & -1.67 & 0.002 & -1.50 & 0.012 \\
\hline PEG10 & -1.40 & 0.001 & -2.01 & 0.025 \\
\hline PLGLB2 & -1.32 & 0.008 & -1.68 & 0.049 \\
\hline PON2 & -1.40 & 0.022 & -1.11 & 0.005 \\
\hline RAB6B & -1.65 & 0.011 & -1.24 & 0.011 \\
\hline RCBTB2 & -1.29 & 0.009 & -1.13 & 0.004 \\
\hline RGMB & -1.41 & 0.009 & -1.08 & 0.003 \\
\hline RHOA & -2.14 & 0.001 & -1.29 & 0.003 \\
\hline SDHD & -2.97 & 0.000 & -1.97 & 0.013 \\
\hline SERINC3 & -2.06 & 0.007 & -1.32 & 0.024 \\
\hline SERTAD2 & -1.94 & 0.002 & -1.47 & 0.000 \\
\hline SESN1 & -1.29 & 0.014 & -1.54 & 0.040 \\
\hline SFT2D3 & -1.03 & 0.027 & -1.39 & 0.010 \\
\hline SLC23A2 & -1.34 & 0.021 & -1.18 & 0.028 \\
\hline SLC25A18 & -1.41 & 0.032 & -2.97 & 0.040 \\
\hline SLC2A4RG & -1.62 & 0.004 & -1.05 & 0.029 \\
\hline SLC44A1 & -1.95 & 0.002 & -1.32 & 0.009 \\
\hline SLC9A6 & -1.58 & 0.002 & -1.61 & $<0.001$ \\
\hline SMN1 & -1.69 & $<0.001$ & -1.14 & 0.003 \\
\hline SMN2 & -1.65 & 0.001 & -1.10 & 0.004 \\
\hline SNORD116-20 & -1.93 & 0.035 & -1.12 & 0.009 \\
\hline SNORD97 & -2.66 & 0.002 & -1.35 & 0.017 \\
\hline SP4 & -1.29 & 0.013 & -1.05 & 0.009 \\
\hline SWAP70 & -2.79 & $<0.001$ & -1.37 & 0.010 \\
\hline TIMMDC1 & -1.72 & $<0.001$ & -1.29 & 0.007 \\
\hline TMED5 & -1.36 & 0.008 & -1.01 & 0.029 \\
\hline TMEM181 & -1.51 & 0.003 & -1.05 & 0.024 \\
\hline TP53INP1 & -2.51 & 0.005 & -2.36 & 0.048 \\
\hline TRIM14 & -2.24 & 0.008 & -1.58 & 0.034 \\
\hline TSC22D3 & -1.04 & 0.023 & -1.27 & 0.032 \\
\hline UBA3 & -1.23 & 0.036 & -1.58 & 0.021 \\
\hline UTRN & -1.37 & 0.031 & -1.43 & 0.002 \\
\hline VAMP3 & -1.60 & 0.003 & -1.45 & 0.010 \\
\hline WRB & -2.12 & 0.005 & -1.98 & 0.006 \\
\hline YIPF6 & -1.12 & 0.005 & -1.21 & 0.001 \\
\hline ZBED6 & -1.22 & 0.016 & -1.35 & 0.030 \\
\hline
\end{tabular}

FC, fold-change; Bcl2110, Bcl-2-like-10; SDHD, succinate dehydrogenase complex subunit D; IDH1, isocitrate dehydrogenase 1 .

Bcl2110-knockdown, whether Bcl2110 regulated the catalyzation of succinate and isocitrate in ovarian cancer cells was further examined. After Bcl2110-siRNA (siBcl2110) treatment of SKOV3 and A 2780 cells for $48 \mathrm{~h}, 1 \times 10^{6}$ cells from each group were harvested and homogenized to measure altered metabolites using colorimetric assay kits. The differentially expressed metabolites in siBcl2110-transfected cells were identified compared with the negative control siRNA (siNC)-transfected cells. As a result, it was revealed that $\mathrm{Bcl} 2110-$ knockdown increased the TCA cycle intermediates succinate and isocitrate. The analysis demonstrated that Bcl2110-knockdown led to elevated levels of succinate in both SKOV3 $(187.86 \mu \mathrm{M}$ in siNC-transfected cells vs. $199.47 \mu \mathrm{M}$ in siBcl2110-transfected cells) and A2780 cells (190.85 $\mu \mathrm{M}$ in siNC-transfected cells vs. 204.36 $\mu \mathrm{M}$ in siBcl2110-transfected cells; $\mathrm{P}<0.05$ ) (Table VI). Furthermore, the levels of isocitrate tended to increase in both SKOV3 (190.27 $\mu \mathrm{M}$ in siNC-transfected cells vs. $201.07 \mu \mathrm{M}$ in siBcl2110-transfected cells) and A2780 cells (180.89 $\mu \mathrm{M}$ in siNC-transfected cells vs. $187.8 \mu \mathrm{M}$ in siBcl2110-transfected cells) after Bcl2110-knockdown (Table VI). These results indicated that $\mathrm{Bcl} 2110$ may affect the catalyzation of succinate and isocitrate through the regulation of SDHD and IDH1 expression.

Bcl2l10-knockdown increases TPM4 expression in ovarian cancer cells. Notably, the current RNA-Seq analysis revealed that among the common DEGs, TPM4 exhibited the greatest increase in expression after Bcl2110-knockdown in both SKOV3 and A2780 cells (Table SI). Through validation by RT-qPCR and western blot analysis, it was confirmed that TPM4 expression was significantly increased after Bcl2110-knockdown at both the mRNA and protein levels (Fig. 4). Based on the fact that TPM4 is involved in early progression of ovarian cancer by altering the actin cytoskeleton (24), these results suggested that $\mathrm{Bcl} 2110$ may also affect cytoskeletal regulation of ovarian cancer cells with TPM4.

\section{Discussion}

Bcl2110 functions as a tumor suppressor gene in gastric cancer and hepatocellular carcinoma. In gastric cancer, $\mathrm{Bcl} 2110$ exhibits a hypermethylated status, which results in low Bcl2110 expression, and Bcl2110-knockdown promotes cell proliferation via activation of the PI3K-Akt signaling pathway $(25,26)$. In hepatocellular carcinoma, $\mathrm{Bcl} 2110$ expression is downregulated, and the overexpression of $\mathrm{Bcl} 2110$ suppresses the activation of JAK-STAT signaling (13). These previous studies imply that the tumor suppressive roles of $\mathrm{Bcl} 2110$ are mediated by different mechanisms under different circumstances depending on the cellular context. In ovarian cancer cells, there have been contradictory results that Bcl2110-suppressed cells exert oncogenic effects despite their decreased expression levels of oncogenic AURKA protein (18). Based on these results, it may be possible that the effects of unknown downstream genes whose expression is regulated by $\mathrm{Bcl} 2110$ may be stronger than those of AURKA expression. Thus, the present study aimed to identify Bcl2110-associated genes by RNA-Seq and demonstrated that DEGs after Bcl2110-knockdown were involved in transcriptional regulation and energy metabolism in ovarian cancer cells.

Zinc finger proteins (ZNFs) are the largest family of transcription factors in the human genome and are involved in numerous cellular processes, including differentiation, 
Table IV. GO analysis of 31 genes commonly upregulated by Bcl2110-knockdown.

A, GO terms (biological process)

\begin{tabular}{llcl}
\hline Accession no. & \multicolumn{1}{c}{ Term } & Count & \multicolumn{1}{c}{ Genes } \\
\hline GO:0006351 & $\begin{array}{l}\text { Transcription, } \\
\text { DNA-templated }\end{array}$ & 13 & $\begin{array}{l}\text { ZNF845, MED11, POLR2D, FOXP4, ZNF415, HABP4, } \\
\text { SETD7, ZNF721, VOPP1, ZNF765, ZSCAN29, ZNF702P, } \\
\text { ZNF267 1.20x10-05 }\end{array}$ \\
GO:0006355 & & & $\begin{array}{l}\text { ZNF845, ZNF415, SETD7, HABP4, VOPP1, ZNF721, } \\
\text { Regulation of }\end{array}$ \\
& $\begin{array}{l}\text { ZNF765, ZNF702P, ZNF267 } \\
\text { transcription, } \\
\text { DNA-templated }\end{array}$ & & \\
\hline
\end{tabular}

B, GO terms (cellular component)

\begin{tabular}{llcl}
\hline Accession no. & Term & Count & Genes \\
\hline GO:0005634 & Nucleus & 15 & $\begin{array}{l}\text { ZNF845, RAD23A, POLR2D, FOXP4, LONP1, HABP4, } \\
\text { OGFR, FIGNL2, ZNF721, FAM32A, ZNF765, ZSCAN29, }\end{array}$ \\
& & & $\begin{array}{l}\text { ZNF702P, ZW10, ZNF267 } \\
\end{array}$ \\
& & &
\end{tabular}

C, GO term (molecular function)

\begin{tabular}{llcl}
\hline Accession no. & Term & Count & \multicolumn{1}{c}{ Genes } \\
\hline GO:0046872 & Metal ion binding & 10 & $\begin{array}{l}\text { ZNF845, ZNF415, LMTK3, ZNF721, ZNF765, CSK, } \\
\text { FOXP4, ZSCAN29, ZNF702P, ZNF267 }\end{array}$ \\
GO:0003697 & $\begin{array}{l}\text { Single-stranded } \\
\text { DNA binding }\end{array}$ & 3 & $\begin{array}{l}\text { LONP1, RAD23A, POLR2D } \\
0.004 ~\end{array}$ \\
\hline
\end{tabular}

GO, Gene Ontology; Bcl2110, Bcl-2-like-10.

development, metabolism, apoptosis, autophagy and stemness maintenance, due to the existence of different combinations of zinc finger motifs (27). Previous studies have reported that $\mathrm{ZNFs}$ regulate cancer progression as tumor suppressor genes (28-30) or oncogenes (31-33). As demonstrated by the current RNA-Seq analysis and subsequent validation of the data, six ZNFs (ZNF845, ZNF415, ZNF721, ZNF765, ZSCAN29 and ZNF267) were significantly upregulated by $\mathrm{Bcl} 2110-$ knockdown. ZNF845 is overexpressed in radiation-induced thyroid carcinoma (34), and ZNF415 is hypermethylated in pancreatic cancer cells (35). ZNF721 and ZNF765 are mutated in peritoneal metastatic gastric adenocarcinoma and non-clear cell renal cell carcinoma, respectively $(36,37)$. The upregulation of ZNF267 expression negatively regulates the transcription of MMP-10 in activated hepatic stellate cells that progress to liver fibrosis and promotes cancer cell proliferation and migration in hepatocellular carcinoma $(38,39)$. Through these ZNFs, $\mathrm{Bcl} 2110$ may induce broad changes in the expression levels of undiscovered downstream genes and affect cancer progression through multiple mechanisms. Additionally, the validation of RNA-Seq data by RT-qPCR revealed that VOPP1 and SETD7 were the most highly upregulated transcription-associated genes in both SKOV3 and A2780 cells, although no significant difference was observed for upregulated VOPP1 expression in
SKOV3 cells. VOPP1, which was previously known as glioblastoma amplified and secreted protein or EGFR-coamplified and overexpressed protein, is most abundant in the thymus and ovary, and is overexpressed in several types of human cancer, including gastric, head and neck, lung and breast cancer (40-42). VOPP1-knockdown in squamous cell carcinoma cells induces apoptosis via the intrinsic pathway (43), whereas the overexpression of VOPP1 promotes cell proliferation and migration in gastric cancer with coamplification (42). The upregulation of VOPP1 expression, a regulator of the apoptotic pathway, after $\mathrm{Bcl} 2110-\mathrm{knockdown}$ suggested a functional association between $\mathrm{Bcl} 2110$ and VOPP1 in mitochondria. As a lysine methyltransferase, SETD7 catalyzes histone H3 lysine 4 (H3K4) methylation followed by the activation of gene expression, which leads to the regulation of several biological processes, such as cell proliferation, differentiation and endoplasmic reticulum stress (44). SETD7 has tumor suppressor functions in gastric cancer (45), but acts as an oncogene in hepatocellular carcinoma (46). These results suggest that $\mathrm{Bcl} 2110$ may induce target gene expression via epigenetic reprogramming.

Notably, the current RNA-Seq analysis revealed that among the common DEGs, TPM4 exhibited the greatest increase in expression after Bcl2110-knockdown in both SKOV3 and A2780 cells. Through validation by RT-qPCR and western 
Table V. GO analysis and KEGG pathway analysis of 92 genes commonly downregulated by Bcl2110-knockdown.

A, GO terms (biological process)

\begin{tabular}{lllll}
\hline Accession no. & \multicolumn{1}{c}{ Term } & Count & Genes & P-value \\
\hline GO:0045669 & $\begin{array}{l}\text { Positive regulation of } \\
\text { osteoblast differentiation }\end{array}$ & 3 & IL6ST, FBN2, GLI3 & 0.033 \\
GO:0016485 & $\begin{array}{l}\text { Protein processing } \\
\text { DNA-templated }\end{array}$ & 3 & CTSS, ADAMTS3, GLI3 & 0.042 \\
GO:0006353 & 2 & SMN2, SMN1 & 0.046 \\
& transcription, termination & & & \\
\hline
\end{tabular}

B, GO terms (cellular component)

\begin{tabular}{|c|c|c|c|c|}
\hline Accession no. & Term & Count & Genes & P-value \\
\hline GO:0005737 & Cytoplasm & 36 & $\begin{array}{l}\text { SLC2A4RG, LRRC8B, FERMT2, UTRN, TRIM14, } \\
\text { HCFC2, MXI1, HPRT1, GLI3, SESN1, PEG10, } \\
\text { TSC22D3, NAA30, CDKN2C, SLC23A2, IDH1, } \\
\text { MASTL, MBNL3, APPBP2, FBXO3, FRS2, } \\
\text { SERTAD2, SWAP70, LIN7C, CD99, SMN2, SMN1, } \\
\text { ATE1, BRWD1, CLIC4, HIPK3, SP4, PCMTD1, } \\
\text { KLHL11, PAICS, TP53INP1 }\end{array}$ & 0.006 \\
\hline GO:0005829 & Cytosol & 25 & $\begin{array}{l}\text { FERMT2, NUDT15, IL32, HPRT1, SESN1, } \\
\text { GLI3, ATP6V1D, SMN2, SMN1, EIF4G2, TSC22D3, } \\
\text { CLIC4, CDKN2C, UBA3, RHOA, IDH1, VAMP3, } \\
\text { RAB6B, MAPK8, FBXO3, ENOPH1, IDI1, PAICS, } \\
\text { EIF5A2, TP53INP1 }\end{array}$ & 0.011 \\
\hline GO:0005793 & $\begin{array}{l}\text { Endoplasmic } \\
\text { reticulum-Golgi intermediate } \\
\text { compartment }\end{array}$ & 3 & RGMB, TMED5, RAB6B & 0.040 \\
\hline GO:0005789 & $\begin{array}{l}\text { Endoplasmic reticulum } \\
\text { membrane }\end{array}$ & 9 & $\begin{array}{l}\text { TMED5, SLC9A6, LRRC8B, RHOA, LCLAT1, } \\
\text { EIF5A2, ARL6IP5, WRB, ACSL5 }\end{array}$ & 0.042 \\
\hline GO:0007504 & Gemini of coiled bodies & 2 & SMN2, SMN1 & 0.049 \\
\hline
\end{tabular}

C, GO term (molecular function)

\begin{tabular}{|c|c|c|c|c|}
\hline Accession no. & Term & Count & Genes & P-value \\
\hline GO:0005515 & Protein binding & 50 & $\begin{array}{l}\text { LRRC8B, ATP6AP2, IL6ST, FERMT2, UTRN, } \\
\text { IL32, HPRT1, MXI1, C1ORF35, SESN1, GLI3, } \\
\text { MED20, RCBTB2, PEG10, FAM49B, TMED5, } \\
\text { NAA30, CDKN2C, ELOVL4, RHOA, RAB6B, } \\
\text { MBNL3, APPBP2, FBN2, FBXO3, ARL6IP5, FRS2, } \\
\text { TIMMDC1, YIPF6, MIEF2, SWAP70, NUDT15, } \\
\text { FZD1, CD164, SMN2, ATP6V1D, SMN1, ATE1, } \\
\text { EIF4G2, CLIC4, UBA3, SP4, LCLAT1, VAMP3, } \\
\text { MAPK8, ADAMTS3, PAICS, EIF5A2, SLC25A18, } \\
\text { TP53INP1 }\end{array}$ & 0.047 \\
\hline
\end{tabular}

D, KEGG pathway analysis ${ }^{\mathrm{a}}$

\begin{tabular}{llcll}
\hline Accession no. & \multicolumn{1}{c}{ Term } & Count & \multicolumn{1}{c}{ Genes } \\
\hline hsa01100 & Metabolic pathways & 10 & ACER2, SDHD, IDH1, LCLAT1, ENOPH1, IDI1, \\
& & & HPRT1, PAICS, ATP6V1D, ACSL5 & 0.070 \\
hsa01130 & Biosynthesis of antibiotics & 4 & SDHD, IDH1, IDI, PAICS \\
hsa05200 & Pathways in cancer & 4 & FZD1, RHOA, MAPK8, GLI3 & 0.064
\end{tabular}


Table V. Continued.

D, KEGG pathway analysis ${ }^{\mathrm{a}}$

\begin{tabular}{lllll}
\hline Accession no. & \multicolumn{1}{c}{ Term } & Count & \multicolumn{2}{c}{ Genes } \\
\hline hsa04722 & $\begin{array}{l}\text { Neurotrophin signaling } \\
\text { pathway }\end{array}$ & 3 & RHOA, MAPK8, FRS2 & 0.096 \\
hsa04071 & Sphingolipid signaling pathway & 3 & ACER2, RHOA, MAPK8 & 0.096 \\
hsa04310 & Wnt signaling pathway & 3 & FZD1, RHOA, MAPK8 & 0.121 \\
hsa04145 & Phagosome & 3 & VAMP3, CTSS, ATP6V1D & 0.138 \\
hsa03013 & RNA transport & 3 & EIF4G2, SMN2, SMN1 & 0.172 \\
hsa05152 & Tuberculosis & 3 & RHOA, MAPK8, CTSS & 0.180 \\
hsa04024 & cAMP signaling pathway & 3 & RHOA, MAPK8, GLI3 & 0.213 \\
\hline
\end{tabular}

${ }^{a}$ Top 10 KEGG pathways, independent of the P-value. GO, Gene Ontology; KEGG, Kyoto Encyclopedia of Genes and Genomes; Bcl2110, Bcl-2-like-10; SDHD, succinate dehydrogenase complex subunit D; IDH1, isocitrate dehydrogenase 1.
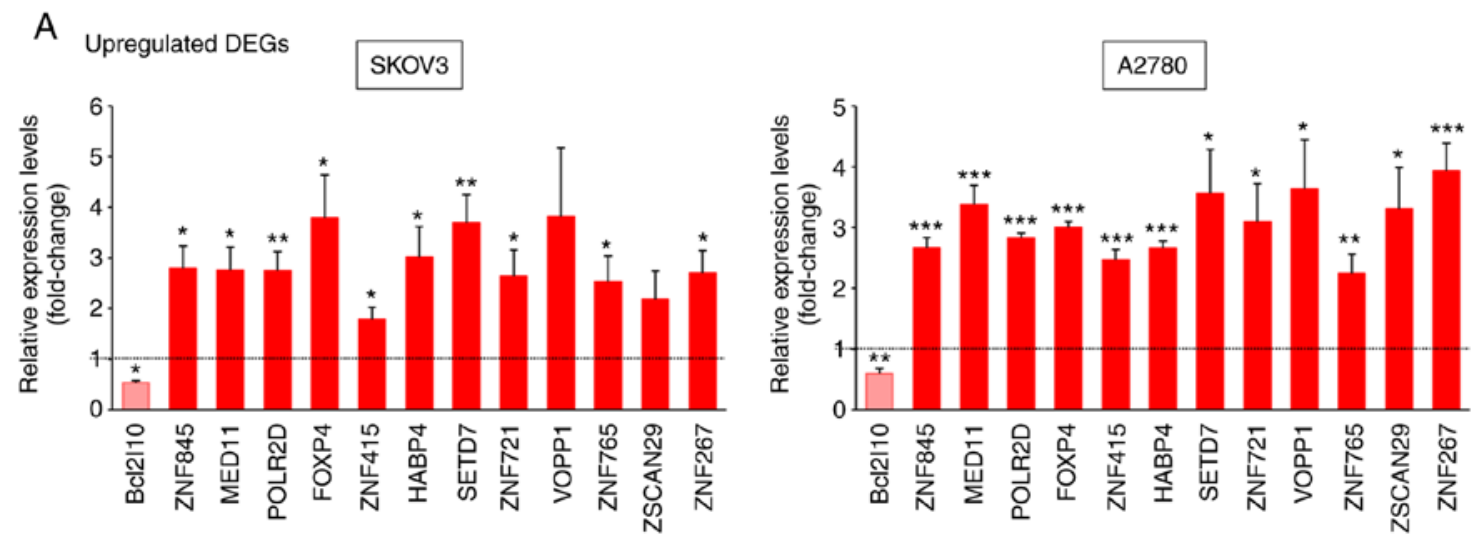

B
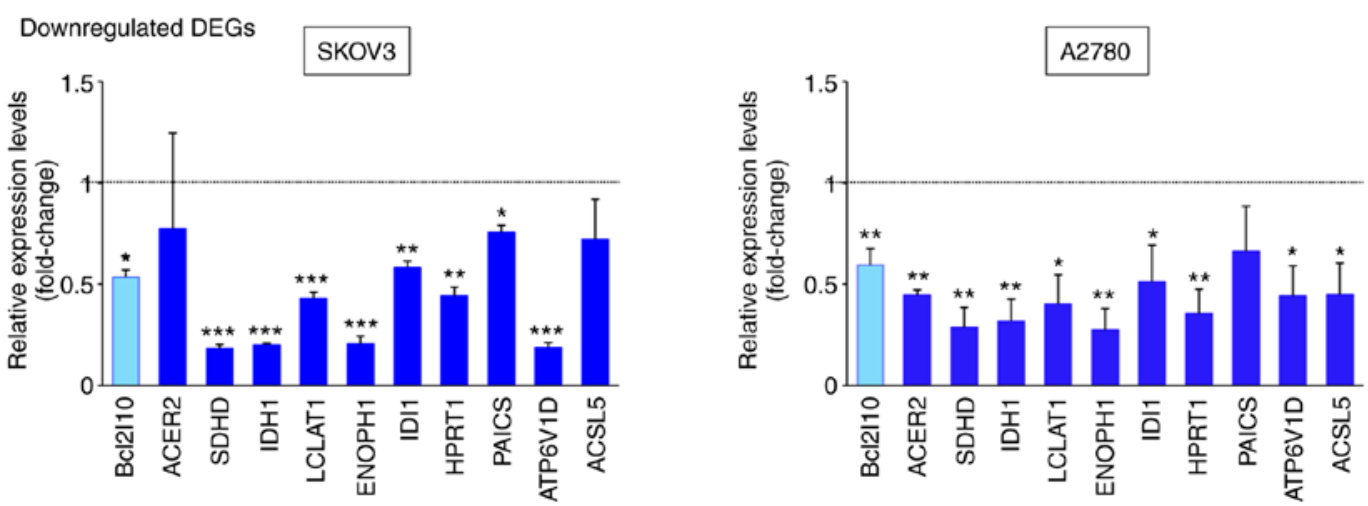

Figure 2. Reverse transcription-quantitative PCR validation of common DEGs after Bcl2110-knockdown. Bar graphs showing the expression levels of (A) commonly upregulated genes involved in the regulation of transcription or (B) commonly downregulated genes involved in metabolic pathways in SKOV3 and A2780 cells. The dashed line on the value 1 indicates the value of each negative control group. All the experiments were repeated at least three times, and the data are expressed as the mean \pm SEM. ${ }^{*} \mathrm{P}<0.05,{ }^{* *} \mathrm{P}<0.01$ and ${ }^{* * * *} \mathrm{P}<0.001$ vs. respective negative control. DEGs, differentially expressed genes; Bcl2110, Bcl-2-like-10.

blot analysis, it was confirmed that TPM4 expression was significantly increased after Bcl2110-knockdown at both the mRNA and protein levels. TPM4 is a member of the tropomyosin family of proteins, which are major structural proteins of the actin cytoskeleton, and mainly regulates the stability of the cytoskeleton in non-muscle cells $(47,48)$. Several studies have demonstrated that TPM4 is expressed at high levels in breast cancer (49), ovarian cancer (50) and non-small cell lung carcinoma (51), and at low levels in squamous cervical cancer (52) and colon cancer (53). According to two-dimensional gel electrophoresis protein profiles, TPM4 is considered a potential marker for the progression of ovarian cancer and breast carcinoma $(24,54)$. A recent study demonstrated that the overexpression of TPM4 in lung cancer cells promotes cell motility by increasing F-actin assembly and has no effect on cell proliferation (51). Therefore, the current RNA-Seq results 
Table VI. Changes in the concentrations of succinate and isocitrate after Bcl2110-knockdown.

\begin{tabular}{|c|c|c|c|c|c|c|}
\hline \multirow[b]{3}{*}{ Metabolites } & \multicolumn{3}{|c|}{ SKOV3 cells } & \multicolumn{3}{|c|}{ A2780 cells } \\
\hline & \multicolumn{2}{|c|}{$\begin{array}{c}\text { Average } \\
\text { concentration, } \mu \mathrm{M}\end{array}$} & \multirow[b]{2}{*}{ P-value } & \multicolumn{2}{|c|}{$\begin{array}{c}\text { Average } \\
\text { concentration, } \mu \mathrm{M}\end{array}$} & \multirow[b]{2}{*}{ P-value } \\
\hline & siNC & siBcl2110 & & siNC & siBcl2110 & \\
\hline Succinate & 187.86 & 199.47 & 0.122 & 190.85 & 204.36 & 0.048 \\
\hline Isocitrate & 190.27 & 201.07 & 0.419 & 180.89 & 187.80 & 0.698 \\
\hline
\end{tabular}

Bcl2110, Bcl-2-like-10; si, small interfering RNA; NC, negative control.

\section{A}
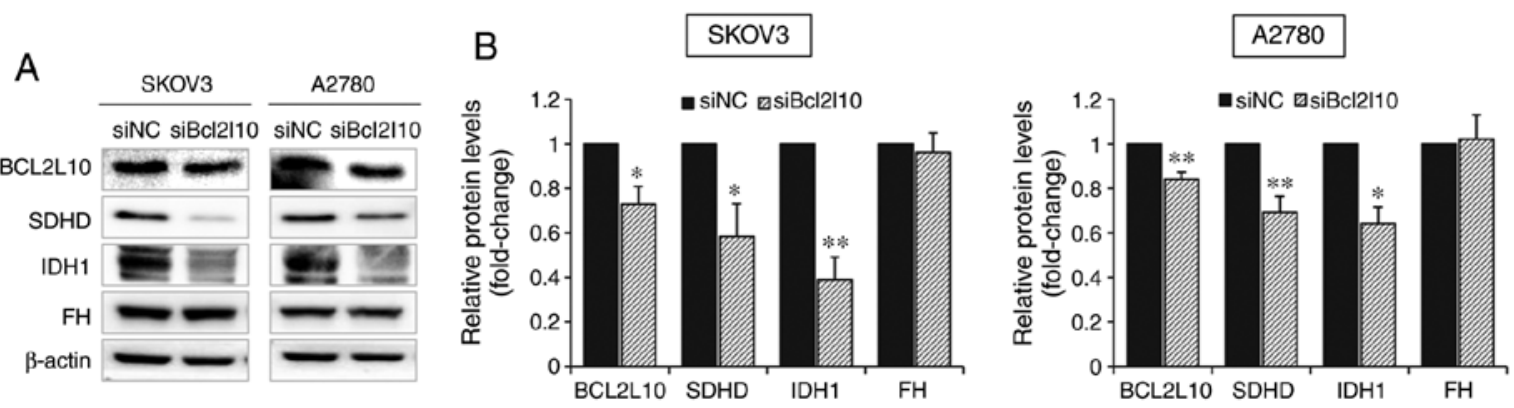

Figure 3. Bcl2110-knockdown significantly decreases the protein expression levels of SDHD and IDH1. (A) SKOV3 and A2780 cells were transfected with siNC or siBcl2110 and harvested $48 \mathrm{~h}$ after transfection. The protein expression levels of BCL2L10, SDHD, IDH1 and FH were measured by western blot analysis using $\beta$-actin as an internal control gene. (B) Protein signals of BCL2L10, SDHD, IDH1 and FH were measured and normalized to the corresponding $\beta$-actin signals. The relative expression levels of proteins were calculated by comparing all the normalized signals to that of the negative control group. All the experiments were repeated at least three times, and the data are expressed as the mean $\pm \mathrm{SEM}$. ${ }^{*} \mathrm{P}<0.05$ and ${ }^{* *} \mathrm{P}<0.01 \mathrm{vs}$. siNC. si, small interfering RNA; NC, negative control; Bcl2110, Bcl-2-like-10; SDHD, succinate dehydrogenase complex subunit D; IDH1, isocitrate dehydrogenase 1; FH, fumarate hydratase.

A

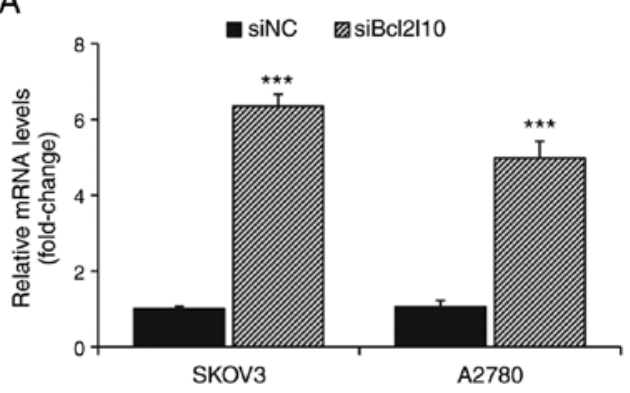

B

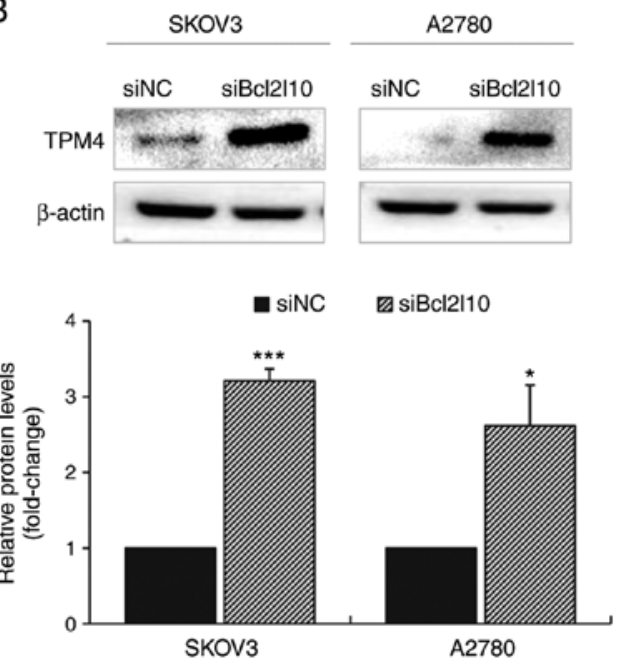

Figure 4. Bcl2110-knockdown significantly increases TPM4 expression. (A) SKOV3 and A2780 cells were transfected with siNC or siBcl2110 and harvested $48 \mathrm{~h}$ following transfection. mRNA expression levels of TPM4 were calculated from CT values obtained by reverse transcription-quantitative PCR and were normalized to the expression levels of GAPDH. (B) Protein levels of TPM4 was measured by western blot analysis. $\beta$-actin was used as an internal control gene. Signals of TPM4 were measured and normalized to corresponding $\beta$-actin signals. Relative expression levels of TPM4 were calculated by comparing all the normalized signals to that of the negative control group. All experiments were repeated at least 3 times, and data are expressed as the mean \pm SEM. ${ }^{*} \mathrm{P}<0.05$ and ${ }^{* * *} \mathrm{P}<0.001$ vs. siNC. si, small interfering RNA; NC, negative control; Bcl2110, Bcl-2-like-10; TPM4, tropomyosin 4.

suggested that the significant increase in cell motility after Bcl2110-knockdown observed in our previous study (18) may be caused by modulation of F-actin assembly following TPM4 upregulation. These results are consistent with our previous study that Bcl2110 directly binds to cytoskeleton-associated proteins, such as actin or tropomyosin, in mouse oocytes, as demonstrated by mass spectrometry analysis (55), and affects spindle assembly during mouse oocyte maturation by 


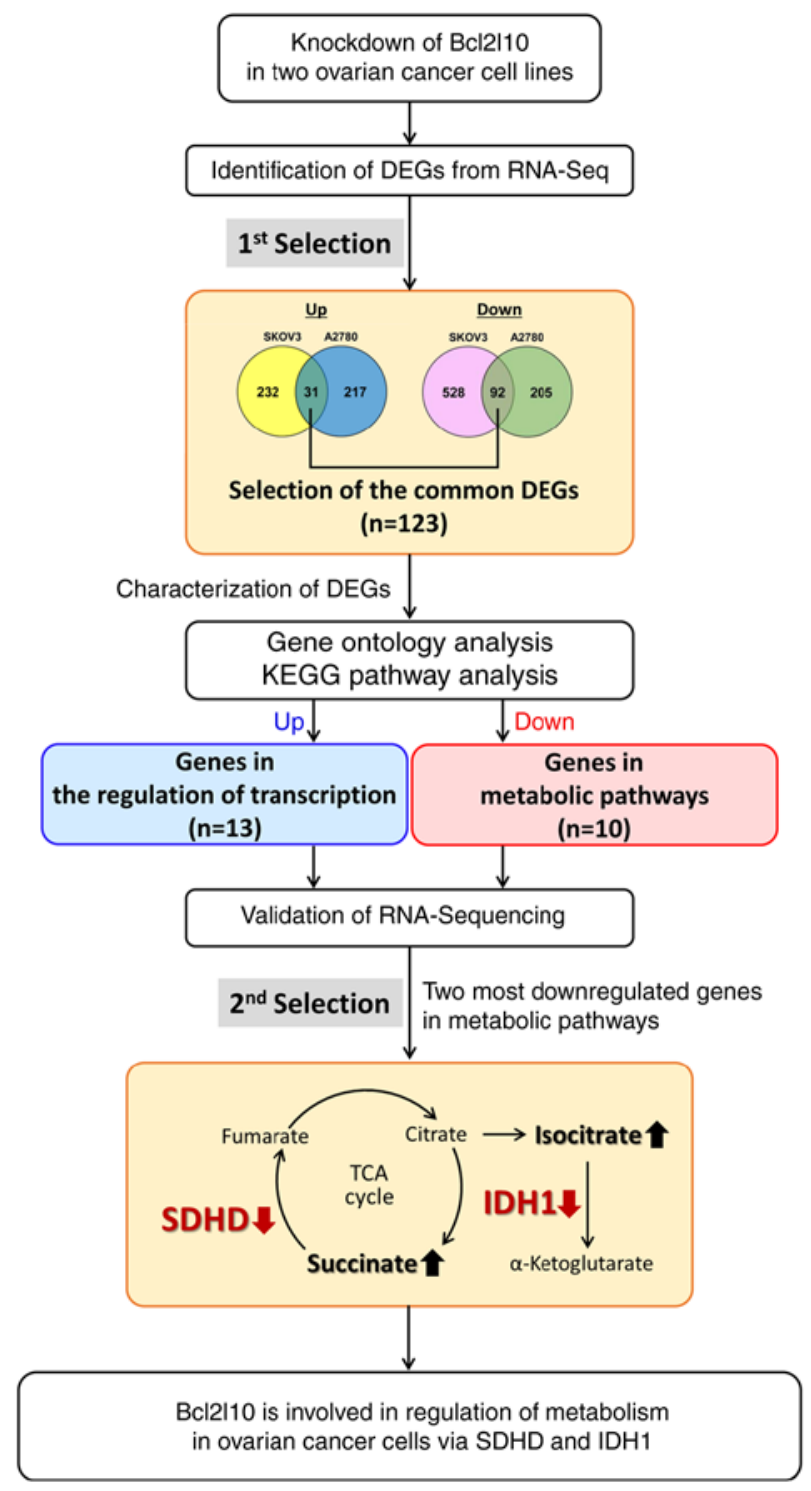

Figure 5. Workflow and summary of study. Overall steps to analyze RNA-Seq data for identifying the role of Bcl2110 and associated genes in ovarian cancer cells. RNA-Seq, RNA sequencing; DEGs, differentially expressed genes; Bc12110, Bcl-2-like-10; KEGG, Kyoto Encyclopedia of Genes and Genomes SDHD, succinate dehydrogenase complex subunit D; IDH1, isocitrate dehydrogenase 1 .

regulating Tpx2 expression, a microtubule-binding protein, and microtubule organizing center-associated proteins (15). Given the importance of the actin cytoskeleton in the invasive and metastatic phenotypes of malignant cancer cells (56), the association between $\mathrm{Bcl} 2110$ and TPM4 may provide new insight into the molecular mechanism through which $\mathrm{Bcl} 2110$ may regulate the actin cytoskeleton in cancer progression.

The findings from the current RNA-Seq analysis revealed that the commonly downregulated DEGs after Bcl2110-knockdown were mainly involved in metabolic pathways, as demonstrated by the KEGG pathway analysis. In addition to functions in apoptotic regulation, numerous proteins of the BCL-2 family, to which Bcl2110 belongs, reside in the mitochondria or translocate to this organelle, which implies that these proteins are involved in normal mitochondrial physiology and metabolism (57). As expected, several studies have reported that BCL-2 family proteins also have non-apoptotic functions associated with carbon substrate utilization (58), electron transport (59), metabolite import (60) and mitochondrial dynamics (57). Although the role of Bcl2110 in mitochondrial metabolism remains unknown, the present identification of Bcl2110 as an upstream gene of SDHD and IDH1, which are key metabolic enzymes in the TCA cycle that affect the production of oncometabolites, such as succinate, fumarate and 2-hydroxyglutarate (2-HG) (61), indicated that Bcl2110 may promote metabolic alterations in cancer progression.

SDHD is one of the four subunits of the SDH complex, which consists of SDHA, SDHB, SDHC and SDHD (62). As a component of the TCA cycle, the SDH complex serves an important role in mitochondrial metabolism by catalyzing the oxidation of succinate to fumarate and inducing electron transport to ubiquinone in the electron transport chain (62). Loss-of-function mutations in SDH members have revealed their role as tumor suppressors in several types of cancer, such as paraganglioma/pheochromocytoma, thyroid cancer (63), ovarian cancer, gastric cancer (64) and renal carcinoma, through induction of the accumulation of succinate and low levels of fumarate (65). The accumulation of succinate increases migration, stem-like phenotypes in thyroid carcinoma cells (63) and angiogenesis through succinate receptor 1-mediated STAT3 and ERK activation (64). In ovarian cancer, dysregulation of SDH members due to genomic deletions occurs frequently, and a high level of succinate is considered as a potential metabolic biomarker for ovarian cancer $(66,67)$. The IDH family is composed of three isozymes (IDH1, IDH2 and IDH3). The enzymatic activities of the wild-type and mutant forms of IDH1/IDH2 differ in the regulation of the TCA cycle (68). Wild-type IDH1 and IDH2 catalyze the conversion of isocitrate to $\alpha$-ketoglutarate $(\alpha-\mathrm{KG})$ at the same time in the cytosol and mitochondria, respectively (68). Moreover, it has been reported that IDH1 and IDH2 mutations confer novel enzymatic activity that facilitates the conversion of $\alpha-\mathrm{KG}$ to $2-\mathrm{HG}$, a potential oncometabolite, in several types of cancer, including glioma, leukemia and breast cancer (69-72). Increased production of 2-HG due to IDH1/IDH2 mutations, which has been observed in glioma and AML, is associated with the induction of oncogenesis $(69,73)$. In primary glioblastoma (GBM), a univariate Cox regression analysis revealed that IDH mutation status was significantly associated with overall survival, but not with age and sex (74). IDH1 expression is upregulated in GBM (75,76), but downregulated in breast cancer (77) compared with in adjacent normal tissues. The loss of $\alpha-K G$ resulting from IDH1 mutations or the knockdown of wild-type IDH1 leads to broad changes in H3K4 methylation that direct cancer cells towards a more differentiated state and results in the inhibition of proliferation in glioma cells (75). As aforementioned, $\mathrm{Bcl} 2110-\mathrm{knockdown}$ in the present study significantly increased SETD7 expression, which also promotes H3K4 methylation (44). These findings suggest that Bcl2110 may cause broad changes in histone methylation to regulate cancer progression.

Notably, SDHD-knockdown in thyroid cancer cells and IDH1-knockdown in breast cancer cells does not affect the proliferative capability of the cells, but promotes cell motility $(63,77)$. Increasing studies have proven that the positive regulation of cell motility is mediated by increased stabilization 
of hypoxia-inducible factor (HIF)-1 $\alpha$, which results from the accumulation of succinate and $\alpha-\mathrm{KG}$ in response to SDHD and IDH1 inhibition (77,78). Although the induction of HIF-1 $\alpha$ after Bcl2110-knockdown was not observed in the present study, the aforementioned results suggest that the significant increase in cell motility after Bcl2110-knockdown detected in our previous study (18) may be caused by the accumulation of succinate and $\alpha-K G$ following the downregulation of SDHD and IDH1 after Bcl2110-knockdown.

Based on our previous results (18), the present study aimed to investigate the mechanism through which $\mathrm{Bcl} 2110$ may regulate cell proliferation and migration in ovarian cancer cells, and revealed that $\mathrm{Bcl} 2110$ may be a new regulator of cancer metabolism. The present study found that the tumorigenic phenotypes in ovarian cancer cells after Bcl2110-knockdown were mediated by alterations in the activities of key TCA cycle enzymes, SDHD and IDH1. Notably, Bcl2110 is associated with metabolic regulation in cancer (57). In the 1930s, Otto Warburg observed that cancer cells prefer aerobic glycolysis over oxidative phosphorylation even under normal oxygen circumstances, known as the Warburg effect (79). The phenomenon of these changes in cancer cells is called metabolic reprogramming, which is considered a hallmark of cancer (80). The Warburg effect has been widely accepted as a common feature of metabolic reprogramming. It has been further postulated that this altered metabolism in cancer cells is due to mitochondrial defects that inhibit the ability of cells to oxidize glucose carbon to $\mathrm{CO}_{2}(81)$. However, in contrast to Warburg's original hypothesis, increasing evidence $(82,83)$ obtained over the last decades has revealed that most cancer cells exhibit unchanged mitochondrial activity to generate the energy required for tumor growth and depend on mitochondrial metabolism as well as glycolysis (84). Instead of the Warburg effect, other studies have proposed two models as new theories regarding the metabolic reprogramming in cancer cells. First, tumor-associated genes may directly cause metabolic alterations. For example, the major oncogenes c-Myc and HIF- $1 \alpha$ are known to promote the expression levels of glycolytic enzymes in tumors and thus serve as master inducers of cancer glycolysis (85), whereas the tumor suppressor p53 directly inhibits the transcription of glucose transporters Glut1 and Glut4, resulting in the downregulation of glucose uptake (86). Based on all these findings, enhanced transcriptional activity of c-Myc and HIF-1 $\alpha$ and decreased p53-mediated control in cancer cells cause upregulation of numerous glycolytic enzymes, such as hexokinase II, phosphofructokinase 1 , triosephosphate isomerase 1 and lactate dehydrogenase A (87). Second, mutations or changes in the expression levels of metabolic genes, such as SDH, IDH and $\mathrm{FH}$, also induce metabolic alterations followed by epigenetic reprogramming, as aforementioned (61). In contrast to the first model, the second model states that tumor-associated gene mutations are a consequence of epigenetic reprogramming (61), and the results of the present study are consistent with the second model. In other words, the alteration in the expression levels of SDHD and IDH1 due to downregulation of the tumor suppressor Bcl2110 may broadly activate the expression levels of other tumor-associated genes through the regulation of transcription factors independent of the Warburg effect.
In conclusion, the current findings demonstrated that Bcl2110 exhibited tumor suppressive roles in ovarian cancer cells via regulating numerous transcription factors and metabolic genes. Functional analysis of these Bcl2110-associated transcription factors and their downstream genes may facilitate obtaining insights into diverse functions of $\mathrm{Bcl} 2110$ in various cancer cells. To the best of our knowledge, the present study is the first to report that $\mathrm{Bcl} 2110$ may be involved in the regulation of the TCA cycle in ovarian cancer cells. The schematic workflow of the current study is shown in Fig. 5.

However, as aforementioned, $\mathrm{Bcl} 2110$ is well known to have different functions in different types of cancer. Therefore, it is necessary to further observe the association between $\mathrm{Bcl} 2110$ and the TCA cycle in other cancer cells to clarify the metabolic regulation of $\mathrm{Bcl} 2110$ in various tissues. Metabolic alteration is one of the hallmarks of cancer and is an important part of cancer research. Further investigation of the contribution of Bcl2110 to cancer metabolism, particularly the regulation of the TCA cycle, may improve the future development of novel cancer treatments.

\section{Acknowledgements}

Not applicable.

\section{Funding}

The present study was supported by the Basic Science Research Program (grant no. NRF-2016R1A2B4013403) and the Bio \& Medical Technology Development program (grant no. NRF-2017M3A9B4061854) of the National Research Foundation funded by the Ministry of Science \& ICT.

\section{Availability of data and materials}

All data generated or analyzed during this study are included in this published article. The raw data (fastq files) generated from RNA-Seq are available in the Gene Expression Omnibus repository (accession no. GSE165766; https://www.ncbi.nlm. nih.gov/geo/query/acc.cgi?acc=GSE165766).

\section{Authors' contributions}

SYL and KAL contributed to conception and design of the present study. SYL performed experiments and wrote the manuscript. JK provided experimental materials and analyzed the data. JK and KAL confirmed the authenticity of the data. KAL provided conceptual advice and revised the manuscript. All authors read and approved the final manuscript.

\section{Ethics approval and consent to participate}

Not applicable.

\section{Patient consent for publication}

Not applicable.

\section{Competing interests}

The authors declare that they have no competing interests. 


\section{References}

1. Siegel RL, Miller KD, Fuchs HE and Jemal A: Cancer Statistics, 2021. CA Cancer J Clin 71: 7-33, 2021.

2. Siegel RL, Miller KD and Jemal A: Cancer statistics, 2018. CA Cancer J Clin 68: 7-30, 2018.

3. Bray F, Ferlay J, Soerjomataram I, Siegel RL, Torre LA and Jemal A: Global cancer statistics 2018: GLOBOCAN estimates of incidence and mortality worldwide for 36 cancers in 185 countries. CA Cancer J Clin 68: 394-424, 2018.

4. Markowska A, Sajdak S, Markowska J and Huczynski A: Angiogenesis and cancer stem cells: New perspectives on therapy of ovarian cancer. Eur J Med Chem 142: 87-94, 2017.

5. Boussios S, Abson C, Moschetta M, Rassy E, Karathanasi A, Bhat T, Ghumman F, Sheriff M and Pavlidis N: Poly (ADP-Ribose) polymerase inhibitors: Talazoparib in ovarian cancer and beyond. Drugs R D 20: 55-73, 2020.

6. Levine B, Sinha SC and Kroemer G: Bcl-2 family members: Dual regulators of apoptosis and autophagy. Autophagy 4: 600-606, 2008

7. Inohara N, Gourley TS, Carrio R, Muñiz M, Merino J, Garcia I, Koseki T, Hu Y, Chen S and Núñez G: Diva, a Bcl-2 homologue that binds directly to Apaf-1 and induces BH3-independent cell death. J Biol Chem 273: 32479-32486, 1998.

8. Kang Y, Lee DC, Han J, Yoon S, Won M, Yeom JH, Seong MJ, Ko JJ, Lee KA, Lee K and Bae J: NM23-H2 involves in negative regulation of Diva and Bcl2L10 in apoptosis signaling. Biochem Biophys Res Commun 359: 76-82, 2007.

9. Naumann U, Weit $\mathbf{S}$, Wischhusen $\mathbf{J}$ and Weller M: Diva/Boo is a negative regulator of cell death in human glioma cells. FEBS Lett 505: 23-26, 2001

10. Zhang H, Holzgreve W and De Geyter C: Bcl2-L-10, a novel anti-apoptotic member of the Bcl-2 family, blocks apoptosis in the mitochondria death pathway but not in the death receptor pathway. Hum Mol Genet 10: 2329-2339, 2001.

11. Cluzeau T, Robert G, Mounier N, Karsenti JM,Dufies M,Puissant A, Jacquel A, Renneville A, Preudhomme C, Cassuto JP, et al: BCL2L10 is a predictive factor for resistance to azacitidine in MDS and AML patients. Oncotarget 3: 490-501, 2012.

12. Nougarede A, Popgeorgiev N, Kassem L, Omarjee S, Borel S, Mikaelian I, Lopez J, Gadet R, Marcillat O, Treilleux I, et al: Breast cancer targeting through inhibition of the endoplasmic reticulum-based apoptosis regulator Nrh/BCL2L10. Cancer Res 78: 1404-1417, 2018.

13. Bai Y, Wang J, Han J, Xie XL, Ji CG, Yin J, Chen L, Wang CK, Jiang XY, Qi W and Jiang HQ: BCL2L10 inhibits growth and metastasis of hepatocellular carcinoma both in vitro and in vivo. Mol Carcinog 56: 1137-1149, 2017.

14. Xu JD, Furuya T, Cao XX, Liu XL, Li QQ, Wang WJ, Xu JW, Xu ZD, Sasaki K and Liu XP: Loss of BCL2L10 protein expression as prognostic predictor for poor clinical outcome in gastric carcinoma. Histopathology 57: 814-824, 2010.

15. Lee SY, Kim EY, Kim KH and Lee KA: Bcl2110, a new Tpx2 binding partner, is a master regulator of Aurora kinase A in mouse oocytes. Cell Cycle 15: 3296-3305, 2016.

16. Damodaran AP, Vaufrey L, Gavard O and Prigent C: Aurora a kinase is a priority pharmaceutical target for the treatment of cancers. Trends Pharmacol Sci 38: 687-700, 2017.

17. Yan M, Wang C, He B, Yang M, Tong M, Long Z, Liu B, Peng F, $\mathrm{Xu}$ L, Zhang Y, et al: Aurora-a kinase: A potent oncogene and target for cancer therapy. Med Res Rev 36: 1036-1079, 2016.

18. Lee SY, Kwon J, Woo JH, Kim KH and Lee KA: Bcl2110 mediates the proliferation, invasion and migration of ovarian cancer cells. Int J Oncol 56: 618-629, 2020.

19. Livak KJ and Schmittgen TD: Analysis of relative gene expression data using real-time quantitative PCR and the 2(-Delta Delta C(T)) method. Methods 25: 402-408, 2001.

20. Trapnell C, Pachter L and Salzberg SL: TopHat: Discovering splice junctions with RNA-Seq. Bioinformatics 25: 1105-1111, 2009.

21. Quinlan AR and Hall IM: BEDTools: A flexible suite of utilities for comparing genomic features. Bioinformatics 26: 841-842, 2010.

22. Roberts A, Trapnell C, Donaghey J, Rinn JL and Pachter L: Improving RNA-Seq expression estimates by correcting for fragment bias. Genome Biol 12: R22, 2011.

23. Laurenti $\mathrm{G}$ and Tennant DA: Isocitrate dehydrogenase (IDH), succinate dehydrogenase (SDH), fumarate hydratase (FH): Three players for one phenotype in cancer? Biochem Soc Trans 44: 1111-1116, 2016.
24. Bailey MJ, Shield-Artin KL, Oliva K, Ayhan M, Reisman S and Rice GE: Stage-specific analysis of plasma protein profiles in ovarian cancer: Difference in-gel electrophoresis analysis of pooled clinical samples. J Carcinog 12: 10, 2013.

25. Mikata R, Fukai K, Imazeki F, Arai M, Fujiwara K, Yonemitsu Y, Zhang K, Nabeya Y, Ochiai T and Yokosuka O: BCL2L10 is frequently silenced by promoter hypermethylation in gastric cancer. Oncol Rep 23: 1701-1708, 2010.

26. Xu JD, Cao XX, Long ZW, Liu XP, Furuya T, Xu JW, Liu XL, De Xu Z, Sasaki K and Li QQ: BCL2L10 protein regulates apoptosis/proliferation through differential pathways in gastric cancer cells. J Pathol 223: 400-409, 2011.

27. Jen $\mathrm{J}$ and Wang YC: Zinc finger proteins in cancer progression. J Biomed Sci 23: 53, 2016

28. Cheng Y, Liang P, Geng H, Wang Z, Li L, Cheng SH, Ying J, Su X, $\mathrm{Ng} \mathrm{KM}, \mathrm{Ng} \mathrm{MH}$, et al: A novel 19q13 nucleolar zinc finger protein suppresses tumor cell growth through inhibiting ribosome biogenesis and inducing apoptosis but is frequently silenced in multiple carcinomas. Mol Cancer Res 10: 925-936, 2012.

29. Harper J, Yan L, Loureiro RM, Wu I, Fang J, D'Amore PA and Moses MA: Repression of vascular endothelial growth factor expression by the zinc finger transcription factor ZNF24. Cancer Res 67: 8736-8741, 2007.

30. Hu R, Peng G, Dai H, Breuer EK, Stemke-Hale K, Li K, Gonzalez-Angulo AM, Mills GB and Lin SY: ZNF668 functions as a tumor suppressor by regulating p53 stability and function in breast cancer. Cancer Res 71: 6524-6534, 2011.

31. Jen J, Lin LL, Chen HT, Liao SY, Lo FY, Tang YA, Su WC, Salgia R, Hsu CL, Huang HC, et al: Oncoprotein ZNF322A transcriptionally deregulates alpha-adducin, cyclin D1 and p53 to promote tumor growth and metastasis in lung cancer. Oncogene 35: 2357-2369, 2016.

32. Serra RW, Fang M, Park SM, Hutchinson L and Green MR: A KRAS-directed transcriptional silencing pathway that mediates the $\mathrm{CpG}$ island methylator phenotype. Elife 3: e02313, 2014.

33. Yang L, Zhang L, Wu Q and Boyd DD: Unbiased screening for transcriptional targets of ZKSCAN3 identifies integrin beta 4 and vascular endothelial growth factor as downstream targets. J Biol Chem 283: 35295-35304, 2008.

34. Bang HS, Choi MH, Kim CS and Choi SJ: Gene expression profiling in undifferentiated thyroid carcinoma induced by high-dose radiation. J Radiat Res 57: 238-249, 2016.

35. Omura N, Li CP, Li A, Hong SM, Walter K, Jimeno A, Hidalgo M and Goggins M: Genome-wide profiling of methylated promoters in pancreatic adenocarcinoma. Cancer Biol Ther 7: 1146-1156, 2008.

36. Durinck S, Stawiski EW, Pavia-Jimenez A, Modrusan Z, Kapur P, Jaiswal BS, Zhang N, Toffessi-Tcheuyap V, Nguyen TT, Pahuja KB, et al: Spectrum of diverse genomic alterations define non-clear cell renal carcinoma subtypes. Nat Genet 47: 13-21, 2015.

37. Liu H, Li F, Zhu Y, Li T, Huang H, Lin T, Hu Y, Qi X, Yu J and Li G: Whole-exome sequencing to identify somatic mutations in peritoneal metastatic gastric adenocarcinoma: A preliminary study. Oncotarget 7: 43894-43906, 2016.

38. Schnabl B, Hu K, Muhlbauer M, Hellerbrand C, Stefanovic B, Brenner DA and Schölmerich J: Zinc finger protein 267 is up-regulated during the activation process of human hepatic stellate cells and functions as a negative transcriptional regulator of MMP-10. Biochem Biophys Res Commun 335: 87-96, 2005.

39. Schnabl B, Valletta D, Kirovski G and Hellerbrand C: Zinc finger protein 267 is up-regulated in hepatocellular carcinoma and promotes tumor cell proliferation and migration. Exp Mol Pathol 91: 695-701, 2011.

40. Baras A and Moskaluk CA: Intracellular localization of GASP/ECOP/VOPP1. J Mol Histol 41: 153-164, 2010.

41. Baras A, Yu Y, Filtz M, Kim B and Moskaluk CA: Combined genomic and gene expression microarray profiling identifies ECOP as an upregulated gene in squamous cell carcinomas independent of DNA amplification. Oncogene 28: 2919-2924, 2009.

42. Gao C, Pang M, Zhou Z, Long S, Dong D, Yang J, Cao M, Zhang C, Han S and Li L: Epidermal growth factor receptor-coamplified and overexpressed protein (VOPP1) is a putative oncogene in gastric cancer. Clin Exp Med 15: 469-475, 2015.

43. Baras AS, Solomon A, Davidson R and Moskaluk CA: Loss of VOPP1 overexpression in squamous carcinoma cells induces apoptosis through oxidative cellular injury. Lab Invest 91: 1170-1180, 2011.

44. Wang H, Cao R, Xia L, Erdjument-Bromage H, Borchers C, Tempst $\mathrm{P}$ and Zhang Y: Purification and functional characterization of a histone H3-lysine 4-specific methyltransferase. Mol Cell 8: 1207-1217, 2001. 
45. Akiyama Y, Koda Y, Byeon SJ, Shimada S, Nishikawaji T, Sakamoto A, Chen Y, Kojima K, Kawano T, Eishi Y, et al: Reduced expression of SET7/9, a histone mono-methyltransferase, is associated with gastric cancer progression. Oncotarget 7: 3966-3983, 2016

46. Chen Y, Yang S, Hu J, Yu C, He M and Cai Z: Increased expression of SETD7 promotes cell proliferation by regulating cell cycle and indicates poor prognosis in hepatocellular carcinoma. PLoS One 11: e0154939, 2016.

47. Manstein DJ and Mulvihill DP: Tropomyosin-mediated regulation of cytoplasmic myosins. Traffic 17: 872-877, 2016.

48. Gunning PW, Hardeman EC, Lappalainen P and Mulvihill DP: Tropomyosin-master regulator of actin filament function in the cytoskeleton. J Cell Sci 128: 2965-2974, 2015.

49. Kabbage M, Trimeche M, Ben Nasr H, Hammann P, Kuhn L, Hamrita B and Chahed K: Tropomyosin-4 correlates with higher SBR grades and tubular differentiation in infiltrating ductal breast carcinomas: An immunohistochemical and proteomics-based study. Tumour Biol 34: 3593-3602, 2013.

50. Tang HY, Beer LA, Tanyi JL, Zhang R, Liu Q and Speicher DW: Protein isoform-specific validation defines multiple chloride intracellular channel and tropomyosin isoforms as serological biomarkers of ovarian cancer. J Proteomics 89: 165-178, 2013.

51. Zhao X, Jiang M and Wang Z: TPM4 promotes cell migration by modulating F-actin formation in lung cancer. Onco Targets Ther 12: 4055-4063, 2019.

52. Lomnytska MI, Becker S, Bodin I, Olsson A, Hellman K, Hellström AC, Mints M, Hellman U, Auer G and Andersson S: Differential expression of ANXA6, HSP27, PRDX2, NCF2, and TPM4 during uterine cervix carcinogenesis: Diagnostic and prognostic value. Br J Cancer 104: 110-119, 2011

53. Yang R, Zheng G, Ren D, Chen C, Zeng C, Lu W and Li H: The clinical significance and biological function of tropomyosin 4 in colon cancer. Biomed Pharmacother 101: 1-7, 2018.

54. Li DQ, Wang L, Fei F, Hou YF, Luo JM, Wei-Chen, Zeng R, Wu J, Lu JS, Di GH, et al: Identification of breast cancer metastasis-associated proteins in an isogenic tumor metastasis model using two-dimensional gel electrophoresis and liquid chromatography-ion trap-mass spectrometry. Proteomics 6: 3352-3368, 2006.

55. Yoon SJ, Kim JW, Choi KH, Lee SH and Lee KA: Identification of oocyte-specific diva-associated proteins using mass spectrometry. Korean J Fertil Steril 33: 189-198, 2006.

56. Yamaguchi $\mathrm{H}$ and Condeelis J: Regulation of the actin cytoskeleton in cancer cell migration and invasion. Biochim Biophys Acta 1773: 642-652, 2007.

57. Gimenez-Cassina A and Danial NN: Regulation of mitochondrial nutrient and energy metabolism by BCL-2 family proteins. Trends Endocrinol Metab 26: 165-175, 2015.

58. Gimenez-Cassina A, Martinez-Francois JR, Fisher JK, Szlyk B, Polak K, Wiwczar J, Tanner GR, Lutas A, Yellen G and Danial NN: BAD-dependent regulation of fuel metabolism and K(ATP) channel activity confers resistance to epileptic seizures. Neuron 74: 719-730, 2012.

59. Perciavalle RM, Stewart DP, Koss B, Lynch J, Milasta S, Bathina M, Temirov J, Cleland MM, Pelletier S, Schuetz JD, et al: Anti-apoptotic MCL-1 localizes to the mitochondrial matrix and couples mitochondrial fusion to respiration. Nat Cell Biol 14 575-583, 2012

60. Malia TJ and Wagner G: NMR structural investigation of the mitochondrial outer membrane protein VDAC and its interaction with antiapoptotic Bcl-xL. Biochemistry 46: 514-525, 2007.

61. Wu W and Zhao S: Metabolic changes in cancer: Beyond the Warburg effect. Acta Biochim Biophys Sin (Shanghai) 45: 18-26, 2013.

62. Huang S and Millar AH: Succinate dehydrogenase: The complex roles of a simple enzyme. Curr Opin Plant Biol 16: 344-349, 2013

63. Ashtekar A, Huk D, Magner A, La Perle K, Zhang X, Piruat JI, López-Barneo J, Jhiang SM and Kirschner LS: Sdhd ablation promotes thyroid tumorigenesis by inducing a stem-like phenotype. Endocr Relat Cancer 24: 579-591, 2017.

64. Mu X, Zhao T, Xu C, Shi W, Geng B, Shen J, Zhang C, Pan J, Yang J, Hu S, et al: Oncometabolite succinate promotes angiogenesis by upregulating VEGF expression through GPR91-mediated STAT3 and ERK activation. Oncotarget 8: 13174-13185, 2017.

65. Ricketts C, Woodward ER, Killick P, Morris MR, Astuti D, Latif F and Maher ER: Germline SDHB mutations and familial renal cell carcinoma. J Natl Cancer Inst 100: 1260-1262, 2008.

66. Aspuria PP, Lunt SY, Varemo L, Vergnes L, Gozo M, Beach JA Salumbides B, Reue K, Wiedemeyer WR, Nielsen J, et al: Succinate dehydrogenase inhibition leads to epithelial-mesenchymal transition and reprogrammed carbon metabolism. Cancer Metab 2: 21, 2014.
67. Zhang T, Wu X, Ke C, Yin M, Li Z, Fan L, Zhang W, Zhang H, Zhao $\mathrm{F}$, Zhou X, et al: Identification of potential biomarkers for ovarian cancer by urinary metabolomic profiling. J Proteome Res 12: 505-512, 2013

68. Reitman ZJ and Yan H: Isocitrate dehydrogenase 1 and 2 mutations in cancer: Alterations at a crossroads of cellular metabolism. J Natl Cancer Inst 102: 932-941, 2010.

69. Turcan S, Rohle D, Goenka A, Walsh LA, Fang F, Yilmaz E, Campos C, Fabius AW, Lu C, Ward PS, et al: IDH1 mutation is sufficient to establish the glioma hypermethylator phenotype. Nature 483: 479-483, 2012

70. Raynaud S, Carbuccia N, Colin C, Adélaïde J, Mozziconacci MJ, Metellus P, Chinot O, Birnbaum D, Chaffanet $M$ and Figarella-Branger D: Absence of R140Q mutation of isocitrate dehydrogenase 2 in gliomas and breast cancers. Oncol Lett 1: 883-884, 2010

71. Rakheja D, Konoplev S, Medeiros LJ and Chen W: IDH mutations in acute myeloid leukemia. Hum Pathol 43: 1541-1551, 2012.

72. Bleeker FE, Lamba S, Leenstra S, Troost D, Hulsebos T, Vandertop WP, Frattini M, Molinari F, Knowles M, Cerrato A, et al: IDH1 mutations at residue p.R132 (IDH1(R132)) occur frequently in high-grade gliomas but not in other solid tumors. Hum Mutat 30: 7-11, 2009.

73. Dang L, White DW, Gross S, Bennett BD, Bittinger MA, Driggers EM, Fantin VR, Jang HG, Jin S, Keenan MC, et al: Cancer-associated IDH1 mutations produce 2-hydroxyglutarate. Nature 462: 739-744, 2009.

74. Prasad B, Tian Y and Li X: Large-Scale analysis reveals gene signature for survival prediction in primary glioblastoma. Mol Neurobiol 57: 5235-5246, 2020.

75. Calvert AE, Chalastanis A, Wu Y, Hurley LA, Kouri FM, Bi Y, Kachman M, May JL, Bartom E, Hua Y, et al: Cancer-associated IDH1 promotes growth and resistance to targeted therapies in the absence of mutation. Cell Rep 19: 1858-1873, 2017.

76. Wahl DR, Dresser J, Wilder-Romans K, Parsels JD, Zhao SG, Davis M, Zhao L, Kachman M, Wernisch S, Burant CF, et al: Glioblastoma therapy can be augmented by targeting IDH1-mediated NADPH biosynthesis. Cancer Res 77: 960-970, 2017.

77. Liu WS, Chan SH, Chang HT, Li GC, Tu YT, Tseng HH, Fu TY, Chang HY, Liou HH, Ger LP and Tsai KW: Isocitrate dehydrogenase 1-snail axis dysfunction significantly correlates with breast cancer prognosis and regulates cell invasion ability. Breast Cancer Res 20: 25, 2018.

78. Selak MA, Armour SM, MacKenzie ED, Boulahbel H, Watson DG, Mansfield KD, Pan Y, Simon MC, Thompson CB and Gottlieb E: Succinate links TCA cycle dysfunction to oncogenesis by inhibiting HIF-alpha prolyl hydroxylase. Cancer Cell 7: 77-85, 2005.

79. Warburg O: On the origin of cancer cells. Science 123: 309-314, 1956.

80. Hanahan D and Weinberg RA: Hallmarks of cancer: The next generation. Cell 144: 646-674, 2011.

81. Warburg O: On respiratory impairment in cancer cells. Science 124: 269-270, 1956.

82. Barbosa IA, Machado NG, Skildum AJ, Scott PM and Oliveira PJ: Mitochondrial remodeling in cancer metabolism and survival: Potential for new therapies. Biochim Biophys Acta 1826: 238-254, 2012

83. Moreno-Sanchez R, Rodriguez-Enriquez S, Marin-Hernandez A and Saavedra E: Energy metabolism in tumor cells. FEBS J 274: 1393-1418, 2007.

84. Koppenol WH, Bounds PL and Dang CV: Otto Warburg's contributions to current concepts of cancer metabolism. Nat Rev Cancer 11: 325-337, 2011.

85. Phan LM, Yeung SC and Lee MH: Cancer metabolic reprogramming: Importance, main features, and potentials for precise targeted anti-cancer therapies. Cancer Biol Med 11: 1-19, 2014.

86. Schwartzenberg-Bar-Yoseph F, Armoni M and Karnieli E: The tumor suppressor 53 down-regulates glucose transporters GLUT1 and GLUT4 gene expression. Cancer Res 64: 2627-2633, 2004.

87. Marbaniang C and Kma L: Dysregulation of glucose metabolism by oncogenes and tumor suppressors in cancer cells. Asian Pac J Cancer Prev 19: 2377-2390, 2018.

This work is licensed under a Creative Commons Attribution-NonCommercial-NoDerivatives 4.0 International (CC BY-NC-ND 4.0) License. 